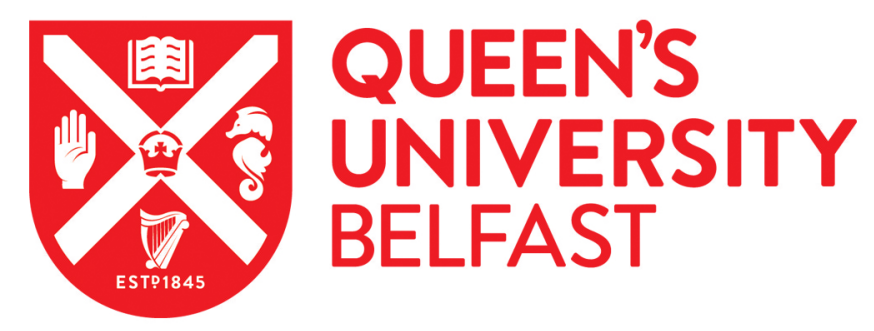

\title{
Defining the potential source region of volcanic ash in northwest Europe during the Mid- to Late Holocene
}

Plunkett, G., \& Pilcher, J. R. (2018). Defining the potential source region of volcanic ash in northwest Europe during the Mid- to Late Holocene. Earth-Science Reviews, 179, 20-37.

https://doi.org/10.1016/j.earscirev.2018.02.006

\section{Published in:}

Earth-Science Reviews

\section{Document Version:}

Peer reviewed version

\section{Queen's University Belfast - Research Portal:}

Link to publication record in Queen's University Belfast Research Portal

\section{Publisher rights}

Copyright 2017 Elsevier.

This manuscript is distributed under a Creative Commons Attribution-NonCommercial-NoDerivs License

(https://creativecommons.org/licenses/by-nc-nd/4.0/), which permits distribution and reproduction for non-commercial purposes, provided the author and source are cited.

\section{General rights}

Copyright for the publications made accessible via the Queen's University Belfast Research Portal is retained by the author(s) and / or other copyright owners and it is a condition of accessing these publications that users recognise and abide by the legal requirements associated with these rights.

Take down policy

The Research Portal is Queen's institutional repository that provides access to Queen's research output. Every effort has been made to ensure that content in the Research Portal does not infringe any person's rights, or applicable UK laws. If you discover content in the Research Portal that you believe breaches copyright or violates any law, please contact openaccess@qub.ac.uk. 


\section{Accepted Manuscript}

Defining the potential source region of volcanic ash in northwest Europe during the Mid- to Late Holocene

Gill Plunkett, Jonathan R. Pilcher

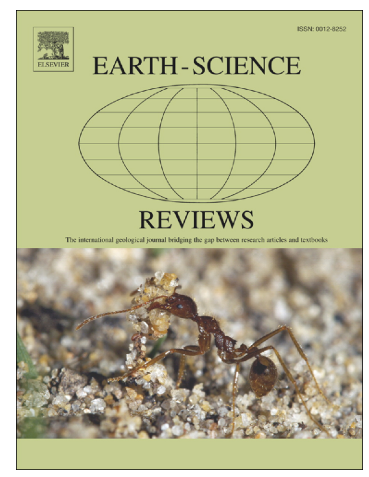

PII:

S0012-8252(17)30569-X

DOI: https://doi.org/10.1016/j.earscirev.2018.02.006

Reference:

EARTH 2584

To appear in:

Earth-Science Reviews

Received date:

4 November 2017

Revised date:

31 January 2018

Accepted date:

6 February 2018

Please cite this article as: Gill Plunkett, Jonathan R. Pilcher, Defining the potential source region of volcanic ash in northwest Europe during the Mid- to Late Holocene. The address for the corresponding author was captured as affiliation for all authors. Please check if appropriate. Earth(2017), https://doi.org/10.1016/j.earscirev.2018.02.006

This is a PDF file of an unedited manuscript that has been accepted for publication. As a service to our customers we are providing this early version of the manuscript. The manuscript will undergo copyediting, typesetting, and review of the resulting proof before it is published in its final form. Please note that during the production process errors may be discovered which could affect the content, and all legal disclaimers that apply to the journal pertain. 


\section{Defining the potential source region of volcanic ash in northwest Europe during the Mid- to Late Holocene}

Plunkett, Gill ${ }^{1 *} \&$ Pilcher, Jonathan R. ${ }^{1}$

${ }^{1}$ Archaeology \& Palaeoecology, School of Natural and Built Environment, Queen's University Belfast, Belfast BT7 1NN, Northern Ireland, UK.

*Corresponding author

\section{Abstract}

Far-travelled volcanic ash (fine-grained tephra) clouds pose economic and societal risks largely through their potential impact on the aviation industry. A long view of ash clouds extending over northwest Europe assembled from the study and geochemical characterization of cryptotephra (i.e. tephra invisible to the naked eye) in sedimentary records can help inform the understanding of the frequency of such events, and the nature of eruptions that generate them. Here we review the records of cryptotephra deposition in northwest Europe during the Mid- to Late Holocene (the last eight millennia) to gain insights into the sources of volcanic ash reaching this region. We consider almost 500 published and unpublished datasets for cryptotephras recorded in sedimentary sequences ranging from Ireland to Latvia and, on the basis of their major element geochemical composition, we identify 90 unique ash horizons and their likely provenance. The majority (72\%) of the cryptotephras derive from Icelandic eruptions, but a large proportion (24\%) originates from other volcanic regions, including Alaska, the Cascades, Kamchatka, Mexico, the Azores and possibly the Mediterranean. Although moderate magnitude eruptions in Iceland may potentially disperse ash clouds over Europe, it appears that only large magnitude events in more distant regions have generally had this capacity and then only when suitable meteorological conditions prevailed. Nevertheless, the cryptotephra records demonstrate that ash clouds from most volcanic regions capable of producing large explosive eruptions in the northern mid- to high latitudes, particularly those to the west of Europe, as well as in tropical North America, have the potential to extend to northwest Europe. Volcanic ash forecasts for this region need therefore to take into account possible risks posed not only by Icelandic eruptions, but also by any large magnitude eruptions in North America or the North Pacific area. 


\section{Keywords}

Cryptotephra; volcanic ash clouds; Holocene tephrostratigraphic framework; tephra source region

\section{Graphical abstract}

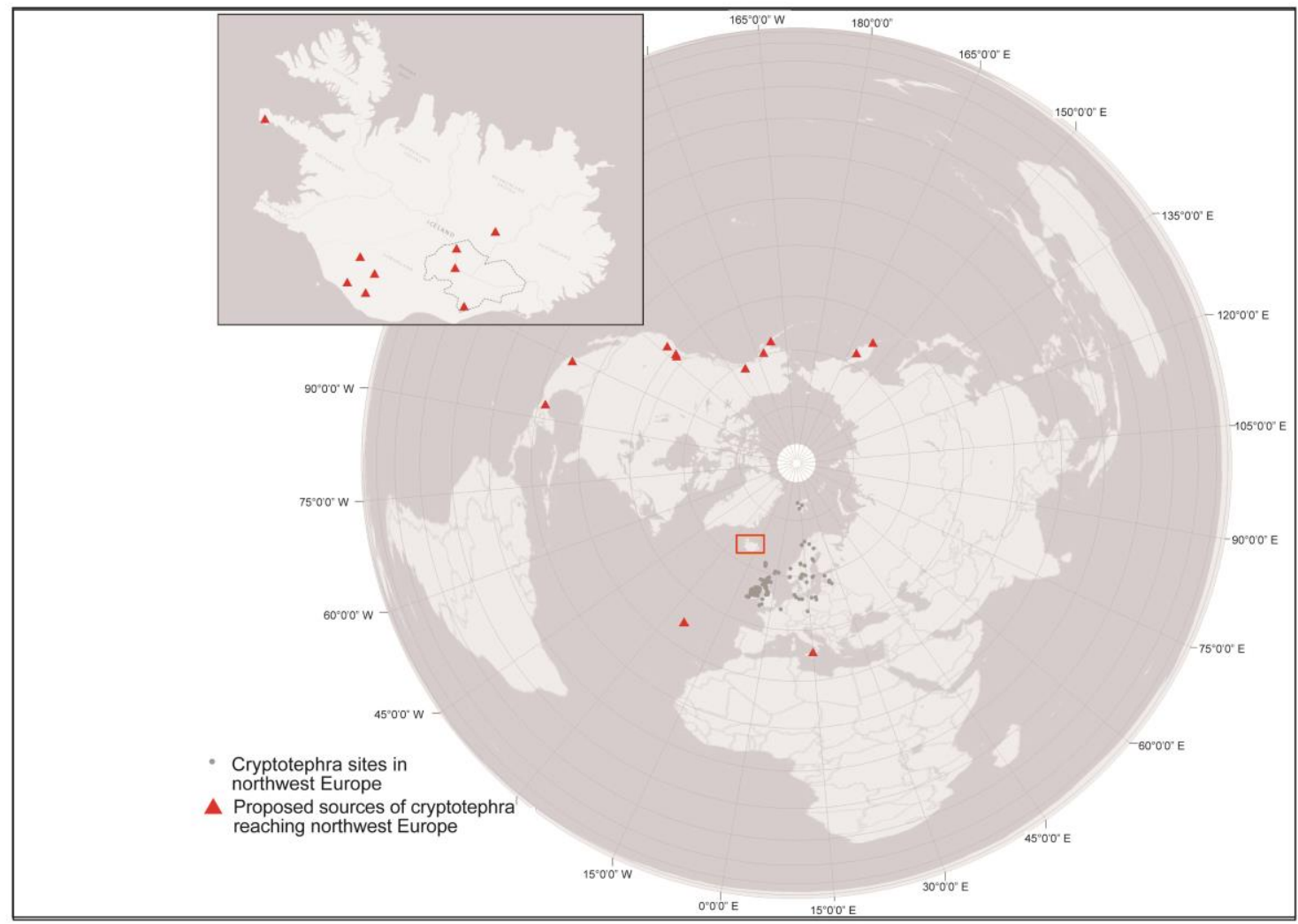

\section{Highlights}

- European cryptotephra records yield evidence for 90 ashfall events in the last 8 ka

- $24 \%$ of cryptotephras are of non-Icelandic origin

- Europe's potential source region of ash includes North American and Asian volcanoes 


\section{$1.0 \quad$ Introduction}

Since the 2010 eruption of Eyjafjallajökull, Iceland, scientific and public interest in volcanic ash (tephra) has grown in Europe, as questions emerge about the frequency, nature and dynamics of ash dispersal, the likelihood of similar events in the future, and the health risks they pose (e.g. Davies et al., 2010; Stevenson et al., 2013). An understanding of ash cloud frequency in Europe, extending back to the last glacial period, can be gleaned from cryptotephra (i.e. tephra components, primarily glass shards, in concentrations too low to be visible to the naked eye) deposited and preserved in sedimentary records far from the erupting volcano (Swindles et al., 2011). Geochemical characterisation of the composition of tephra-derived glass shards enables the ash to be correlated with its source, providing the glass component of tephra at the source has itself been characterised. Peat bogs and lake sediments offer long, continuous records of past ashfall, and have proven to be rich repositories of cryptotephras in northwest Europe (Persson, 1971; Dugmore et al., 1992; Pilcher et al., 1992). Although a range of taphonomic and other issues (e.g. meteorological conditions, eruption style) limit the extent to which the distal records reflect the true frequency of past ash clouds in a region as large as northwest Europe, cryptotephra deposits nevertheless signify a minimum level of such exposure. Temporal and spatial analyses have thus demonstrated ashfall over Ireland, northern Britain and Scandinavia, in particular, at an average rate of approximately two events per century, and more occasionally to areas south of the Baltic Sea (Swindles et al., 2011; Lawson et al., 2012; Watson et al., 2017b).

The proximity of Iceland, coupled with the ready availability of published reference geochemical datasets for Icelandic eruptions, has helped shape the view of this region as the predominant source of ash clouds over northern Europe (e.g. Watson et al., 2017b). The correlation of the AD860B tephra with the White River Ash tephra from Mount Churchill, Alaska (Jensen et al., 2014), drew attention for the first time to the possibility of "ultradistal" tephra in Europe; this tephra can now be traced $~ 7,000 \mathrm{~km}$ from source to eastern Poland (Watson et al., 2017a). Indeed, tephrochronological research on the western North Atlantic seaboard (Pyne-O’Donnell et al., 2012; Mackay et al., 2016) and in Greenland (Coulter et al., 2012; Jensen et al., 2014; Sun et al., 2014) has demonstrated the presence of ash from a range of volcanic sources, including Mexico (Ceboruco?), the Cascades (Mount St Helens, Newberry and Mazama), Alaska (Churchill and Augustine), Kamchatka (Ksudach), 
Japan (Tamurai?) and China (Changbaishan), during the Mid- to Late Holocene. What factors have therefore prevented such long-travelled tephras from being recorded in Europe? Was the AD860B tephra an exceptional ash-cloud, or have other factors hindered the recognition of non-Icelandic cryptotephras in this region?

The growing international network of tephrochronologists working on both sides of the Atlantic, and the increasing availability of full geochemical datasets for North American (e.g. Kaufman et al., 2012; Wallace et al., 2014) and east Asian (e.g. Ponomareva et al., 2015) Holocene volcanic eruptions, has prompted us to reconsider the many "unknown" cryptotephras and unidentified "outliers" within our own database of glass-based tephra geochemical analyses at Queen's University Belfast. We extend our data review to published cryptotephra records from northwest Europe, building upon previously published catalogues (Swindles et al., 2011; Watson et al., 2017b). We limit our analysis to the Mid- to Late Holocene, as the tephrostratigraphic framework of the Late Glacial and Early Holocene has recently been summarised (Blockley et al., 2014). With reference to published proximal and distal datasets, we outline the geographical extent of the provenances of the cryptotephras in order to define the potential source region for ash clouds reaching northwest Europe.

\subsection{Cryptotephra data collection}

\subsection{Data handling}

We have compiled glass-based tephra geochemical data from as many published sources as we could identify, aided by the recent catalogue produced by Watson et al. (2017b). We add to this a large number of previously unreported analyses of cryptotephras undertaken by researchers at Queen's University Belfast, and make the data available for the first time (Supplementary File 1). Where possible, we include secondary glass standards associated with the analyses. Because many of the samples were analysed in the 1990 s and early 2000 s before secondary standards were routinely reported, however, not all secondary data have been retained, but their measurement was routine to ensure instrumental precision. We consider too the presence of minor populations, sometimes reported as outliers, and attempt to distinguish data that can be matched to sources from spurious results arising from the inadvertent analysis of mineral inclusions in the glass. Unlike Watson et al. 
(2017b), we do not include cryptotephras whose glass compositions have not been confirmed by geochemical analysis. Using a series of biplots, we compare and correlate the geochemical suites using normalised data and, where possible, with published proximal and/or distal datasets. Selected biplots are provided to demonstrate previously unrecognised correlations.

A small number of published cryptotephra datasets have been excluded from this compilation, either because the data quality was inadequate (e.g. energy dispersive spectrometry analysis of unpolished samples at West Corlea - Caseldine et al., 1998) or because the proposed deposits comprise heterogeneous populations that may merely represent intermixing from adjacent tephras (e.g. Loch Portain - Dugmore et al., 1992; BGMT1 - Langdon and Barber, 2002; CF-4 - Watson et al., 2017a). Proposed tephra attributions at Ricksby Ball, England (Fyfe et al., 2014), have also been omitted, as the suggested correlations conflict with other dating evidence from the site, and no geochemical data are published for independent evaluation. The significance of $\mathrm{OMH}-185$ Population 2 (Plunkett et al., 2004a) is also dismissed, as geochemical analyses from this cryptotephra contain a considerable amount of scatter due to the presence of microlite (mineral) inclusions.

\subsection{Nomenclature}

Where cryptotephras can be correlated with a known eruption or tephra horizon, we attribute the commonly accepted event name to that isochron. We retain, however, the label "AD860B" for the cryptotephra that has now been correlated with the North American White River Ash east lobe (WRAe) due to the former's prevalence in literature relating to the European cryptotephra record. In the absence of an international protocol for naming previously unreported cryptotephras, we use the system adopted by Hall and Pilcher (2002) of coding an isochron (event) with reference to the site and depth at which it was first identified (e.g. GB4-150 was first found in Garry Bog monolith 4 at a depth of $150 \mathrm{~cm}$ ). To differentiate individual samples that correlate with specific isochrons, we use the unique identifiers applied to all tephra samples in Queen's University Belfast (i.e., those prefixed by the code QUB) or the local identifiers used by other researchers, if available. 
In this paper, we refer to the age of the tephras using the Common Era (CE/BCE) timescale to avoid confusion between the conventional use of BP ("before present", referenced to $1950 \mathrm{CE}$ ) and the recent usage of the term to refer to "years before 2000" (e.g. Watson et al., 2017b). All radiocarbon-based age estimations are given as calendar-year equivalents (at 95\% confidence intervals).

\subsection{The northwest European cryptotephra record}

On the basis of the cryptotephra deposits for which geochemical compositions are available, we identify 90 events that we consider to derive from individual volcanic ash clouds (Supplementary File 2). Prolific tephrostratigraphies at a small number of sites (notably, Borge, Garry and An Loch Mór) add many unique events to the cryptotephra record, but more than half of the cryptotephras are replicated at two or more sites. The geographical positions of the three aforementioned sites - perched at the edge of the Atlantic seaboard may be a factor in their rich cryptotephra records. We propose certain and possible sources for all but three of the 90 cryptotephras based on geochemical correlations. We find that 22 (24\%) have glass geochemistries that are not consistent with Icelandic volcanic provenances (Fig. 1). 


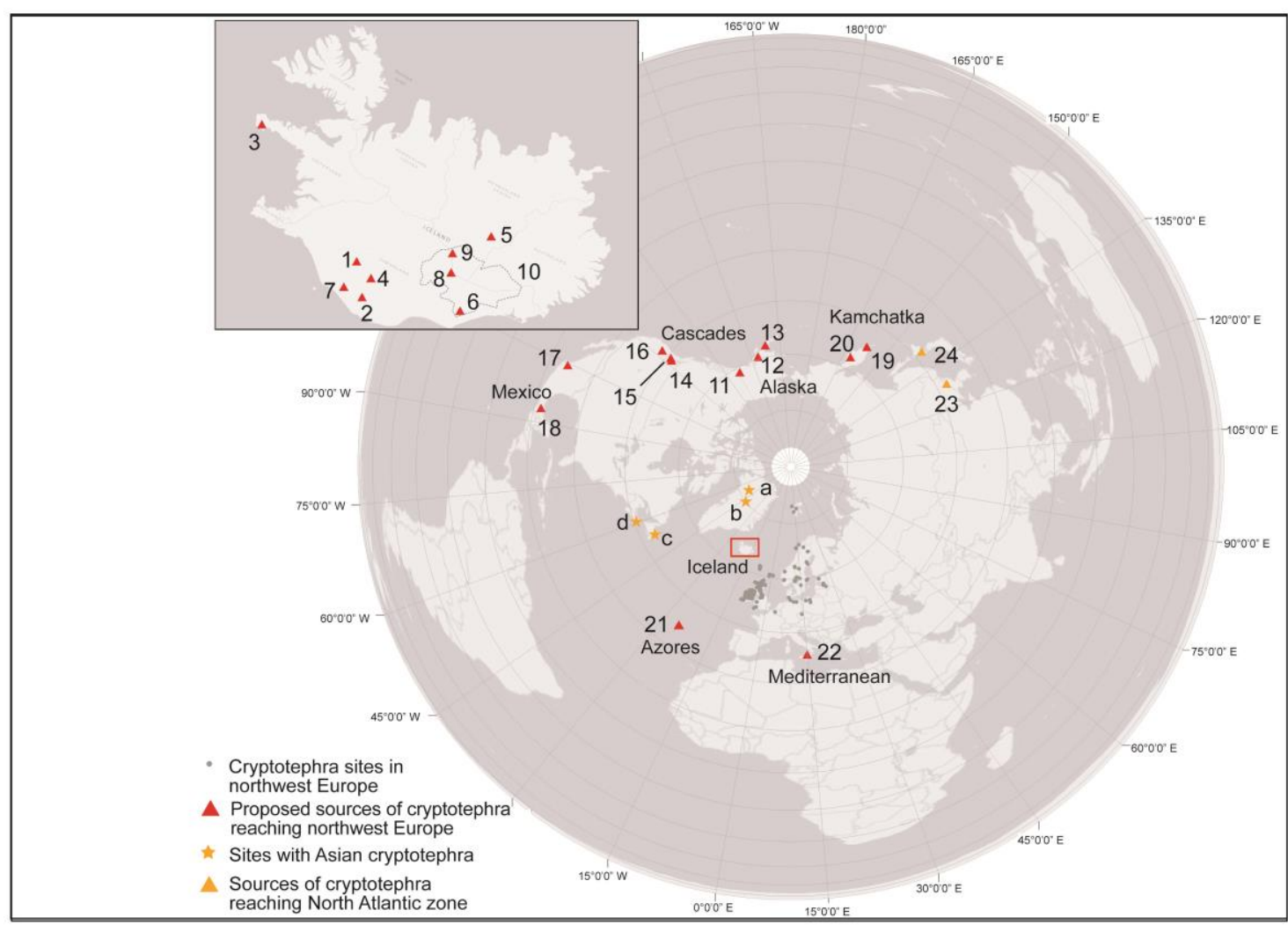

Fig. 1. Location of volcanoes discussed in the text. 1 Hekla; 2 Katla; 3 Snaefellsjökull; 4 Torfajökull; 5 Askja; 6 Öraefajökull; 7 Eyjafjalljökull; 8 Grímsvötn; 9 Veidivötn-Bárdarbunga; 10 area of Vatnajökull icecap; 11 Churchill; 12 Augustine; 13 Aniakchak; 14 Rainier; 15 Mount St Helens; 16 Crater Lake; 17 Ceboruco; 18 El Chichón; 19 Ksudach; 20 Shiveluch; 21 Furnas; 22 Lipari; 23 Changbaishan; 24 Tamurai. Locations of sites in the North Atlantic region in which Asian cryptotephra has been found are also noted: a NEEM; $b$ NGRIP; $c$ Nordan's Pond; $d$ Framboise Bog.

Following a review of the published data, a small number of tephrostratigraphies have been re-interpreted. These include the record from Borge, Norway (Pilcher et al., 2005), as correlations can now be made with the AD860B, Ey H and Hekla Ö tephras (see Supplementary File 3 for updated tephrostratigraphy and revised age-model). Similarities between mixed tephra suites at Borge and Kongressvatnet, Svalbard (D'Andrea et al., 2012), also call for a reconsideration of the correlation of a Snaefellsjökull population at the latter site with the Sn-1 tephra. We suggest that a correspondence with a younger Snaefellsjökull unit seen at Borge is more likely. Lastly, the chronology of the Whitehorse Hill profile, 
England, was poorly resolved due to the presence of non-unique cryptotephras (Fyfe et al., 2016). We re-evaluate the attributions of these units in the light of the wider regional cryptotephra framework.

\subsection{Iceland}

\subsubsection{Hekla}

Hekla is one of Iceland's most active volcanoes, and has produced a number of large, explosive eruptions (VEI 5) during the Holocene (Hekla 1104, Hekla 3, Hekla 4, Hekla Ö, Hekla 5), interspersed with frequent events of lesser magnitude. Tephra from Hekla can range from rhyolitic to basaltic, the silicic tephras associated with the more voluminous eruptions, particularly after a period of volcanic quiescence (Larsen and Thorarinsson, 1977). Some glass geochemical suites are, however, inseparable on the basis of their major element compositions. Although isopach maps often indicate dispersal of Hekla tephra towards the north of the volcano (e.g. Larsen and Thorarinsson, 1977; Larsen et al., 2014), the distal record demonstrates that ash has frequently been transported to the east and southeast towards continental Europe (Table 1).

Crytoptephras from Hekla 1104 (also known as Hekla 1) and Hekla 4 ( 2300 BCE) were amongst the earliest to be recorded in Britain and Ireland (Dugmore et al., 1995; Pilcher et al., 1995) and have since been widely reported as far west as Estonia (Hang et al., 2006). Long-standing uncertainty surrounded the correlation of the Hekla cryptotephra known as Lairg A ( 4900 BCE; Pilcher et al., 1996) with the Hekla 5 tephra of 5100 BCE due to what appeared to be slight differences in their glass geochemistries (Dugmore et al., 1995). Normalisation of data shows that the populations are, in fact, indistinguishable, and it is highly likely that they are from the same event. Cryptotephra from the much-discussed Hekla 3 event, for a time implicated in a hypothesis of volcanically-forced climate downturn in the 12th century BCE (Baillie and Munro, 1988), was subsequently found in Ireland (Plunkett, 1999; 2006) and in Germany, where it was dated to the 11th century BCE (van den Bogaard and Schmincke 2002). Less well-known is the Hekla Ö eruption ( 4100 BCE), data from which have only recently been reported (Gudmundsdóttir et al., 2011). On the basis of its geochemistry and age estimate, we now propose that this tephra is represented at Borge, Norway (QUB-602: Pilcher et al., 2005; Fig. 2). 

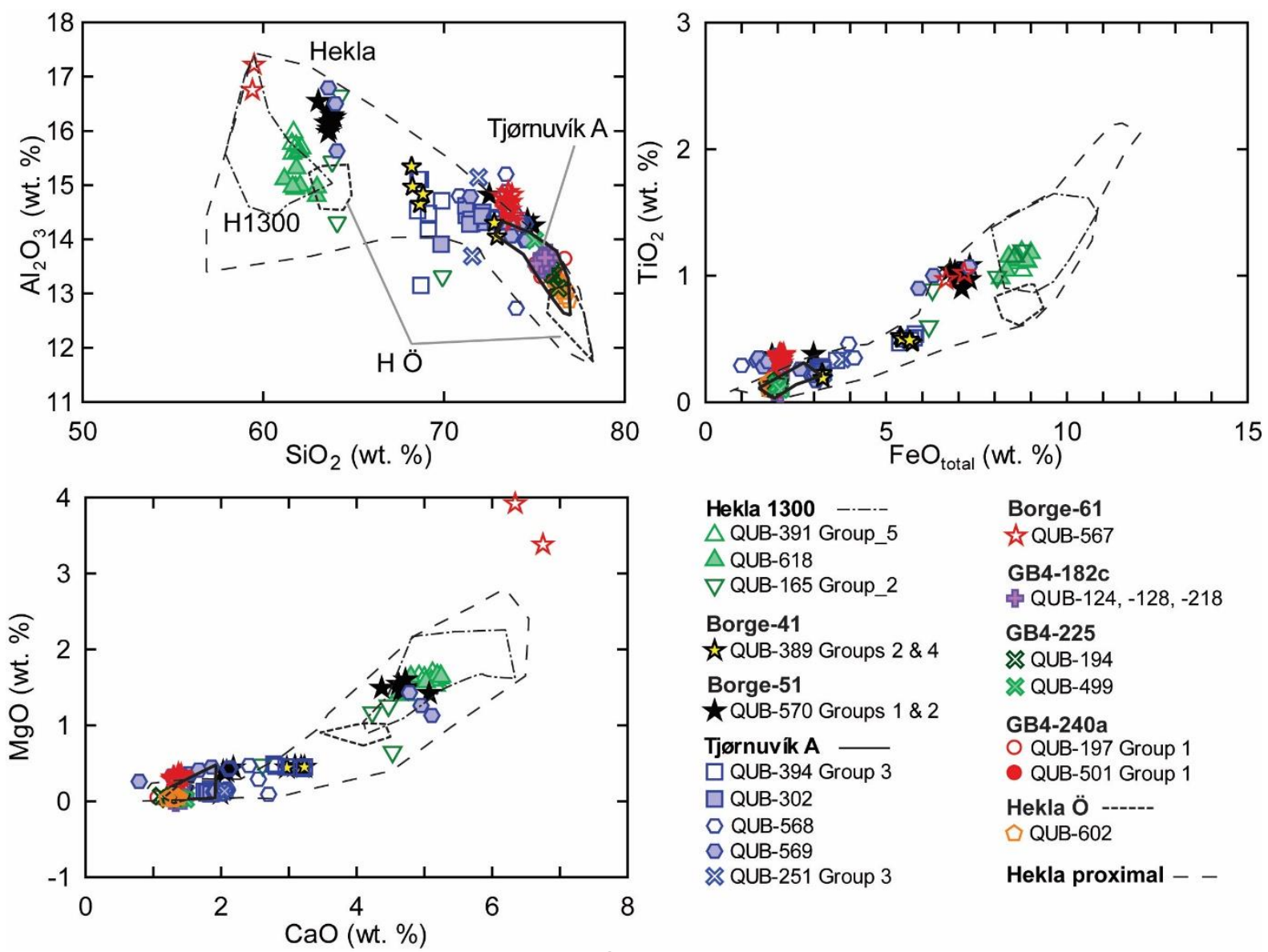

\begin{tabular}{|c|c|}
\hline $\begin{array}{l}\text { Hekla } 1300-\cdot-\cdot- \\
\triangle \text { QUB-391 Group_5 }\end{array}$ & $\begin{array}{l}\text { Borge-61 } \\
\star \hbar \text { QUB-567 }\end{array}$ \\
\hline $\begin{array}{l}\triangle \text { QUB-618 } \\
\nabla \text { QUB-165 Group_2 }\end{array}$ & $\begin{array}{l}\text { GB4-182c } \\
\text { 답 QUB-124, -128, -218 }\end{array}$ \\
\hline $\begin{array}{l}\text { Borge-41 } \\
\text { ^ QUB-389 Groups } 2 \text { \& } 4\end{array}$ & $\begin{array}{l}\text { GB4-225 } \\
\text { × QUB-194 }\end{array}$ \\
\hline $\begin{array}{l}\text { Borge-51 } \\
\text { QUB-570 Groups } 1 \& 2\end{array}$ & « QUB-499 \\
\hline $\begin{array}{l}\text { Tjørnuvík A }- \\
\square \text { QUB-394 Group } 3\end{array}$ & $\begin{array}{l}\text { GB4-240a } \\
\text { QUB-197 Group } 1 \\
\text { QUB-501 Group } 1\end{array}$ \\
\hline $\begin{array}{l}\square \text { QUB-302 } \\
0 \text { QUB-568 } \\
\text { QUB-569 } \\
\text { \ QUB-251 Group } 3\end{array}$ & $\begin{array}{l}\text { Hekla Ö ----- } \\
\triangle \text { QUB-602 } \\
\text { Hekla proximal - - }\end{array}$ \\
\hline
\end{tabular}

Fig. 2. Glass-shard major element analyses of previously unreported cryptotephras originating from Hekla (including newly provenanced data originally published by Pilcher et al., 2005). Compositional envelopes for glass of Hekla tephra (andesitic to silicic components) are based on proximal data from Dugmore et al. (1992; 2007), Boygle (1994), Larsen et al. (1999; 2002) and Streeter and Dugmore (2014). Hekla 1300 (H1300) envelopes are based on Boygle (1994), Larsen et al. (2002) and Dugmore et al. (2007), and the Hekla Ö (H Ö) envelopes (excluding outliers) on Gudmundsdóttir et al. (2011). The compositional range for glass shards of Tjørnavik $A$ in the Faroe Islands is also shown (based on Hannon et al., 1998; Wastegård et al., 2001; Wastegård, 2002).

The cryptotephra records also include material from a number of VEI 4 eruptions. Hekla Selsund (also known as Kebister) was first reported from Sweden by Boygle (1998) and is now a widespread marker, albeit with a distinctly northern bias. Hekla 1947 ashfall was documented historically (Thorarinsson, 1954) and the cryptotephra has subsequently been found at many Irish and Scottish sites (see Supplementary File 2). Hekla 1510 has proven to 
be another useful isochron in Ireland and Scotland (Dugmore et al., 1995; Pilcher et al., 1996; see Supplementary File 2), but has not yet been identified in other areas. Hekla cryptotephras from the historical eruptions in 1158, 1300, 1693 and 1845 have also been recorded but they have a more limited distribution (see Supplementary File 2). Differentiation of the many historical Hekla tephras is, however, complicated by the close major element geochemical composition of their glasses, and cryptotephra from other eruptions may not have been recognised as discrete units. The BMR-190 tephra ( 650 BCE) is also of Hekla origin, possibly correlating with the Hekla-A, $-\mathrm{Y}$ or $-\mathrm{Z}$ unit recorded proximally (Plunkett et al., 2004a).

Many other Hekla eruptions are additionally identified in the distal records (Table 1; Fig. 2). These include a stratigraphically distinct series of four cryptotephras in Borge, Norway (Pilcher et al., 2005), that date to between the eighth and tenth centuries CE, although the attribution of Borge-61 to Hekla is not entirely certain on geochemical grounds. At least one of these deposits seems to be replicated elsewhere, namely that dating to $850 \mathrm{CE}$ based on its co-occurrence with the AD860B tephra. We propose a correlation between this event and the Tjørnuvík A cryptotephra identified in the Faroes (Hannon et al., 1998; Wastegård et al., 2001; Wastegård, 2002) where it is found in association with the Settlement tephra ( $\sim 70 \mathrm{CE})$. With due consideration of age, glass major element geochemistry and tephrostratigraphic positions, we furthermore propose that the rhyolitic component of the MOR-T6 cryptotephra from An Loch Mór, Ireland (Chambers et al., 2004), as well as a number of other Hekla-type populations in Ireland, also derive from the same event and reveal a more extended geochemical range than the Faroes datasets (Fig. 2). In Sweden, there appears to be a Hekla eruption represented by cryptotephras at $~ 50 \mathrm{BCE}$ at Kortlandamossen (Kort2 $328-330 \mathrm{~cm}$ : Borgmark and Wastegård, 2008) and perhaps Svartkälsjärn Lake (SV-L2: Watson et al., 2016). Other Hekla correlatives currently represented at individual sites include the DOM-4 Group 2 ( $400 \mathrm{CE}$ ) in Germany (van den Bogaard and Schmincke, 2002), GB4-182c ( 1640 BCE: this paper) in Ireland, SV-L4 ( 40003000 BCE) in Sweden (Watson et al., 2016), and possibly Borge-179 ( 5200 BCE) in Norway (Pilcher et al., 2005). 
In Ireland, three closely spaced cryptotephras comprising Hekla 4-type glass were noted at Toome (Plunkett et al., 2004b). Initially considered as a possible taphonomic issue, this phenomenon has now been observed at a number of other sites in the north of Ireland, together implying that an earlier ( 2600 BCE) and a later ( 2300 BCE) eruption produced an ash identical to Hekla 4 rhyolitic glass end-member. Where multiple Hekla 4-type units are found, we consider the Hekla 4 event to be distinguishable by the very high concentration of shards that is typically observed at most sites where it is present. The older and younger units do not demonstrate such high concentrations.

\subsubsection{Katla}

Katla is another of Iceland's most active volcanoes, with at least $~ 208$ explosive eruptions recorded for the mid- to Late Holocene (Óladóttir et al., 2005). Although most of its products have a basaltic composition, Larsen et al. (2001) report at least 12 silicic tephras (known as "SILK", denoting silicic Katla units) during the Holocene whose glass-shard major elemental geochemistry is mainly dacitic to trachydacitic, and only occasionally rhyolitic. The geochemistry varies little between eruptions, but a long repose time has been considered necessary to allow the silicic magma to accumulate (Larsen et al., 2001).

In the distal record, we identify eight cryptotephras whose glass compositions fall within the dacitic/trachydacitic range of the SILK tephras (Table 1; Fig. 3), including possible correlatives for the SILK-UN tephra (GB4-150, 780 BCE), SILK-N4 (GB4-198a, 1900 BCE), SILK-N2 ( 2350 BCE), SILK-A1 ( 3800 BCE) and SILK-A7 ( 5200 BCE). GA4-85, which is found widely in Ireland (see Supplementary File 2), is dated through its close stratigraphic position with the AD860B tephra to $800 \mathrm{CE}$, and is therefore younger than the youngest reported SILK tephra (SILK-Yn, 400 CE: Larsen et al., 2001). It may have been erupted during the same event that produced the Hrafnkatla tephra ( 760 CE; Óladóttir et al., 2011) or the eruption that produced the jökulhlaup that flooded a birch forest west of Katla in $822 / 3 \mathrm{CE}$ (Büntgen et al., 2017), if these were indeed two separate events. Borgmark and Wastegård, (2008) also found some Katla dacite-like shards mixed within the Askja 1875 cryptotephra at Fågelmossen, which they attributed possibly to the 1860 CE Katla eruption. 
Table 1. Cryptotephras of Icelandic origin in northwest Europe

\begin{tabular}{|c|c|}
\hline Source & Tephra name (age) \\
\hline \multirow[t]{9}{*}{ Hekla } & Hekla 1947 (1947 CE), Hekla 1845 (1845 CE), Hekla 1693 (1693 CE), Hekla \\
\hline & 1510 (1510 CE), Hekla 1300 (1300 CE), Hekla 1158 (1158 CE), Hekla 1104 \\
\hline & (1104 CE), Borge-41 ( 950 CE), Borge-51 ( 860s CE), Tjørnuvík A ( 850s \\
\hline & $\mathrm{CE})$, Borge-61? ( 770 CE), DOM-4 Group 2 ( 400 CE), KORT-328 ( 50 \\
\hline & BCE), BMR-190 (705-585 BCE), Hekla 3 (1087-1006 BCE), GB4-182a \\
\hline & ( 1640 BCE), Hekla Selsund/Kebister (1800-1750 BCE), GB4-225 ( 2300 \\
\hline & BCE), Hekla 4 (2395-2279 BCE), GB4-240a ( 2600 BCE), SV-L4 ( 4000- \\
\hline & 3000 BCE), Hekla Ö ( 4100 BCE), Hekla 5 [Lairg A] (4997-4902 BCE), \\
\hline & Borge-179 ( 5200 BCE) \\
\hline \multirow[t]{6}{*}{ Katla } & FGM1-23 [Katla 1860?] ( 1875 CE), BTD-15 ( 1650-1750 CE), GB4-50 \\
\hline & ( 1250 CE), BMR-90 ( 920 CE), GA4-85 ( 800 CE), GB4-150 [SILK-UN?] \\
\hline & (800-758 BCE), GB4-198a [SILK-N4?] ( 1900 BCE), GW-173 [SILK-N2?] \\
\hline & ( 2395-2279 BCE), HOV-42 [SILK A1?] (4240-3770 BCE), Mjáuvøtn A \& B \\
\hline & (4776-4512 BCE), HOV-63 [SILK-A7?] (5470-4980 BCE), Suduroy (6360- \\
\hline & $5910 \mathrm{BCE})$ \\
\hline Snaefellsjökull & Borge-26 ( 1362 CE), BTD-41 ( 950 CE), LBA-2 [Sn-2?] (1700-1600 BCE) \\
\hline Torfajökull & $\begin{array}{l}\text { GB4-45b ( 1250 CE), Settlement [Landnám] ( 870s CE), Gullbergby? } \\
\text { ( 750 BCE), SLU10-104 ( 3800 BCE), Hoy? (4680-4260 BCE), Lairg B } \\
\text { (4774-4677 BCE) }\end{array}$ \\
\hline Askja & $\begin{array}{l}\text { Askja } 1875 \text { (1875 CE), BTD-48 ( 870s CE), Stömyren ( 150 BCE), Glen } \\
\text { Garry (260-16 BCE) }\end{array}$ \\
\hline Öraefajökull & Öraefajökull 1362 (1362 CE) \\
\hline Eyjafjallajökull & Eyjafjallajökull 2010 (2010 CE), Ey H (420-620 CE) \\
\hline \multirow[t]{2}{*}{ Grímsvötn } & Grímsvötn 1903 (1903 CE), Laki 1783 (1783 CE), CLA-L1 [Grímsvötn \\
\hline & 1354?] ( 1300s CE), TSK11-240 ( 870 CE), Hov (4240-3770 BCE) \\
\hline \multirow[t]{2}{*}{ Veidivötn-Bárdarbunga } & Veidivötn 1477 (1477 CE), SVL1-11 [Veidivötn 1159?] ( 1100s CE), \\
\hline & Settlement [Landnám] ( 870s CE) \\
\hline \multirow[t]{2}{*}{ Vatnajökull unlocated } & Borge-15 ( 1650-1750 CE), AD860A (853 CE \pm 10 ), Microlite [OMH-185] \\
\hline & (755-680 BCE), GB4-198b ( 1900 BCE), GB4-240b ( 2600 BCE) \\
\hline
\end{tabular}

Basaltic and rhyolitic Katla tephras are represented by the Mjáuvøtn A and Suduroy cryptotephras, respectively (Wastegård et al., 2001; Wastegård, 2002). Glass of the 
Mjáuvøtn B cryptotephra has a trachyandesitic composition that lies between the basaltic and dacitic fields of Katla eruptives, and we hypothesise that this represents an intermediate product from the same event as the Mjáuvøtn A cryptotephra (Fig. 3a). Similarly, we find that a number of low silica ( 70 wt. \%, normalised) rhyolites have a composition that falls directly between the dacitic and rhyolitic Katla populations (Fig. 3). These include the GB4-50 (low silica rhyolite only), BMR-90 (low silica rhyolite only), and the BTD-15 tephra (multi-modal, comprising also the higher silica and dacitic populations; Pilcher et al., 2005). We argue that the glass compositions of these tephras illustrate a transitional component of Katla tephra that has not previously been reported, perhaps only erupted in small volume during the most explosive phases of the eruptions.

BTD-15 has an age estimate of 1650-1750 CE (Pilcher et al., 2005). Although there were several Katla eruptions in this timeframe, the 1755 CE event was the most voluminous, and may therefore have been the source of the BTD-15 tephra. Ashfalls from both the 1755 and 1660 CE eruptions were, however, observed in Europe (Thorarinsson 1981), making a certain correlation impossible without further chronological refinement. The GB4-50 tephra is stratified above the AD860B horizon and has an age estimate of 925 CE (Hall and Pilcher, 2002). It may correlate with Katla-R 925 CE (Gudmundsdóttir et al., 2012) but another possibility is that it was produced during the major Eldgjá eruption of 938/9 CE. A dacitic population of glass was found with the basaltic end-member of the Eldgjá tephra in the GISP2 ice core in Greenland (Zielinski et al., 1995). Its geochemical composition varies in some respects from the BMR-90 cryptotephra, but the relatively small departures may be attributable to instrumental and/or methodological differences in the analytical technique. The age of the GB4-50 cryptotephra is estimated to be 1250 CE, based on its stratigraphic position between Hekla 1158 and Öraefajökull 1362 at Garry Bog, Ireland (Hall and Pilcher, 2002). A possible correlative is difficult to determine, as a number of Katla eruptions took place in the 13th century. 

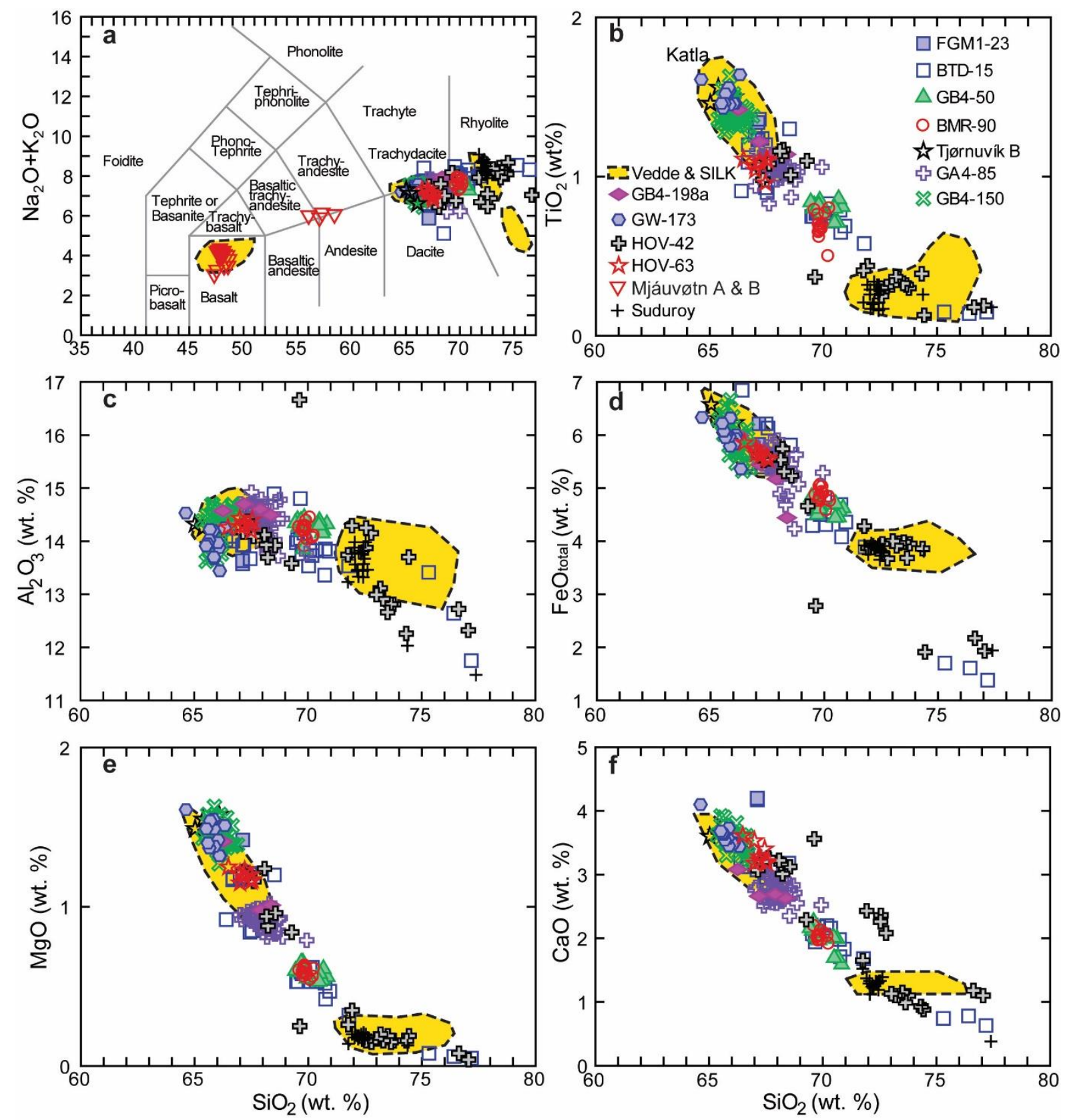

Fig. 3. Glass-shard major element analyses of cryptotephras of proposed Katla origin (see Supplementary File 2 for sample details and references): a) Total alkali silica (TAS) classification based on Le Bas et al. (1986); $b$ to f) selected oxide to silica ratios for the silicic populations. Compositional envelopes for Katla are based on published data for the Late Glacial Vedde Ash (Mangerud et al., 1984; Turney et al., 1997; Wastegård et al., 1998; 2000; Björck and Wastegård, 1999; Zillén et al., 2002; Koren et al., 2008; Gudmundsdóttir et al., 2012) and SILK tephras (Larsen et al., 2001). 


\subsubsection{Snaefellsjökull}

Jóhannesson et al. (1981) identified three Holocene-age Snaefellsjökull tephras in Iceland, but geochemical data on constituent glasses are available only for the youngest ( $160 \mathrm{CE})$ of these layers, Sn-1 (Larsen et al., 2001; Holmes et al., 2016). More recent Snaefellsjökull tephra at Baulárvallavatn, western Iceland, has been interpreted as reworked material because no eruptions younger than Sn-1 are known from this system (Holmes et al., 2016). Cryptotephras with similar glass geochemistry have been identified in Kongressvatnet, Svalbard (Kongress 39-44 cm, Group 2: D’Andrea et al., 2012), and Sammakovuoma lake and bog, Sweden (SL-2, SB-2: Watson et al., 2016), where they have been correlated with Sn-1 (Fig. 4). Snaefellsjökull-type cryptotephras (BTD-41/BIP-24a) have also been recorded at Borge and nearby sites in Norway (Pilcher et al., 2005), but in these instances they are firmly stratified above the Settlement tephra and date to the tenth century CE. A further occurrence can found be at Borge (QUB-385 Group 1: Pilcher et al., 2005) and Kongressvatnet (Kong 19-21 cm (unknown): D’Andrea et al., 2012) where cryptotephra of Sn-1 type is mixed with Öraefajökull 1362 ash. These cryptotephras provide strong evidence for more recent and previously unreported Snaefellsjökull eruptions. In consideration of the available dating information at Kongressvatnet and Sammakovuoma, we propose that the Snaefellsjökull cryptotephras identified at these sites correlate with BTD-41 rather than Sn1. Older cryptotephra with a Snaefellsjökull affinity has also been recorded at Lilla Backsjömyren, Sweden, and a possible correlation with the Sn-2 tephra, of similar age, has been proposed (Wastegård et al., 2009). 

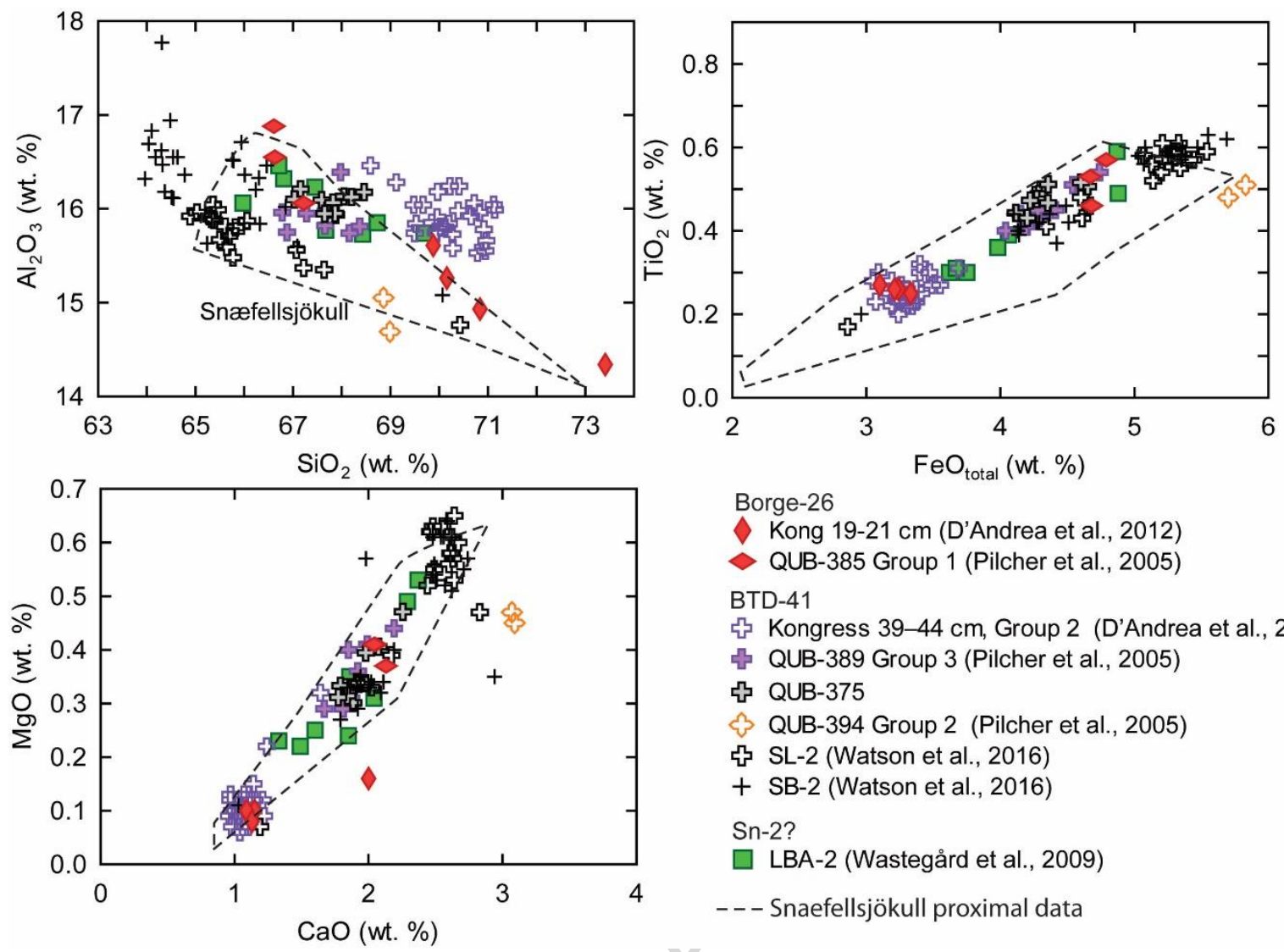

Borge-26

$\checkmark$ Kong 19-21 cm (D’Andrea et al., 2012)

$\checkmark$ QUB-385 Group 1 (Pilcher et al., 2005)

BTD-41

फ Kongress 39-44 cm, Group 2 (D’Andrea et al., 2012)

QUB-389 Group 3 (Pilcher et al., 2005)

њ QUB-375

\& QUB-394 Group 2 (Pilcher et al., 2005)

њ SL-2 (Watson et al., 2016)

+ SB-2 (Watson et al., 2016)

Sn-2?

$\square$ LBA-2 (Wastegård et al., 2009)

- - Snaefellsjökull proximal data

Fig. 4. Glass-shard major element analyses of cryptotephras from Snaefellsjökull.

Compositional envelopes for Snaefellsjökull are based on proximal data from Larsen et al. (2001) and Holmes et al. (2016).

\subsubsection{Torfajökull}

Torfajökull is a central volcano closey linked to the Veidivötn-Bárdarbunga fissure, and the synchronous eruption of the two systems at 1477 CE, 870s CE and 150 CE yielded bimodal tephras comprising a rhyolitic end member from Torfajökull and a basaltic component from Veidivötn (Larsen 1984). The 870s CE event produced the Settlement (or Landnám) tephra, both components of which have been identified in Greenland ice cores (Grönvold et al., 1995; Zielinski et al., 1997). Torfajökull ash from this event is also present at Borge, Norway (QUB-571 Group 2: Pilcher et al., 1995), and possibly also Roman Lode, Britain (Layer 3 Group 3: Matthews 2008). Shards of Torfajökull-type have additionally been identified amongst other cryptotephras at Garry Bog (GB4-45b: this paper) and Claraghmore Bog (CLB2 high alkali component: Watson et al., 2016), suggesting a possible eruption in or around the 12/13th century CE. The geochemical compositions of glasses of the Gullbergby ( 750 BCE; Wastegård, 2005), Hoy ( 4400 BCE; Dugmore et al., 1995) and Lairg B ( 4700 BCE; 
Pilcher et al., 1996) cryptotephras indicate that these too derive from Torfajökull. Lairg B has the widest geographical distribution of any of the Torfajökull units. In view of their close age estimates, and considering that both cryptotephras have yet to be identified together in any one site, it remains uncertain whether the Hoy and Lairg B cryptotephras derive from the same or separate eruptions. A younger Torfajökull cryptotephra (SLU10-104: this paper) is, however, recorded above Lairg B at Sluggan Bog, Ireland, but with an interpolated age estimate of $3800 \mathrm{BCE}$, it is too young to be correlated with the Hoy deposit.

\subsubsection{Askja}

Cryptotephra from the caldera-forming eruption of Askja in 1875 has been widely reported in Europe, with a northerly distribution extending to the east Baltic area. Ashfall following this event was historically documented in Scandinavia (Thorarinsson, 1981). An earlier proximal deposit, the $A \sim 2000$, has recently been correlated on the basis of its glass geochemistry with the Glen Garry cryptotephra (Gudmundsdóttir et al., 2016) found at a large number of sites in Britain, as well as in Germany (Supplementary File 2), and dated to 260-16 BCE (Barber et al., 2008). The Stömyren tephra identified in Sweden has a glassderived geochemical composition and age estimate similar, but not identical to, the Glen Garry tephra, and has been considered to represent a separate Askja event (Wastegård, 2005). Hartley et al. (2016) have identified further eruptives from Askja dating to $1510 \mathrm{CE}$ and $1341 \mathrm{CE}$ in Iceland. Neither of these events is represented by cryptotephra in Europe, but shards with Askja composition (BTD-48) are found mixed with Settlement cryptotephra at Borge, Norway (Pilcher et al., 2005), possibly signifying another unreported eruption.

\subsection{6. Öraefajökull}

The Öraefajökull 1362 CE tephra was one of the first cryptotephras to be identified in Europe (Pilcher et al., 1996). Its constituent glass has a distinct geochemistry, easily separable from those of other Icelandic sources. The cryptotephra has a rather restricted distribution, found only in the north of Ireland and in Norway, but it has also been firmly identified in the central Greenland GRIP ice core (Coulter et al., 2012) and possibly also GISP2 (Palais et al., 1991). Cryptotephra from a smaller eruption in 1727 has not yet been reported. 


\subsubsection{Eyjafjallajökull}

Ash from the 2010 eruption of Eyjafjallajökull extended over a large part of continental Europe, with particles detected as far south as Iberia and Italy, and as far west as Budapest (e.g. Stevenson et al., 2012). Its glass-based geochemistry has been characterised at PrahaSuchdol, Czech Republic (Navrátil et al., 2013), although the proximal and distal datasets demonstrate considerable scatter. At least four previous eruptions are known to have occurred at Eyjafjallajökull. The recent characterisation of the Ey H layer ( 420-620 CE) by Dugmore et al. (2013) has now enabled QUB-565 from Borge, Norway (Pilcher et al., 2005), to be correlated with this event, and has helped refine the Borge chronology.
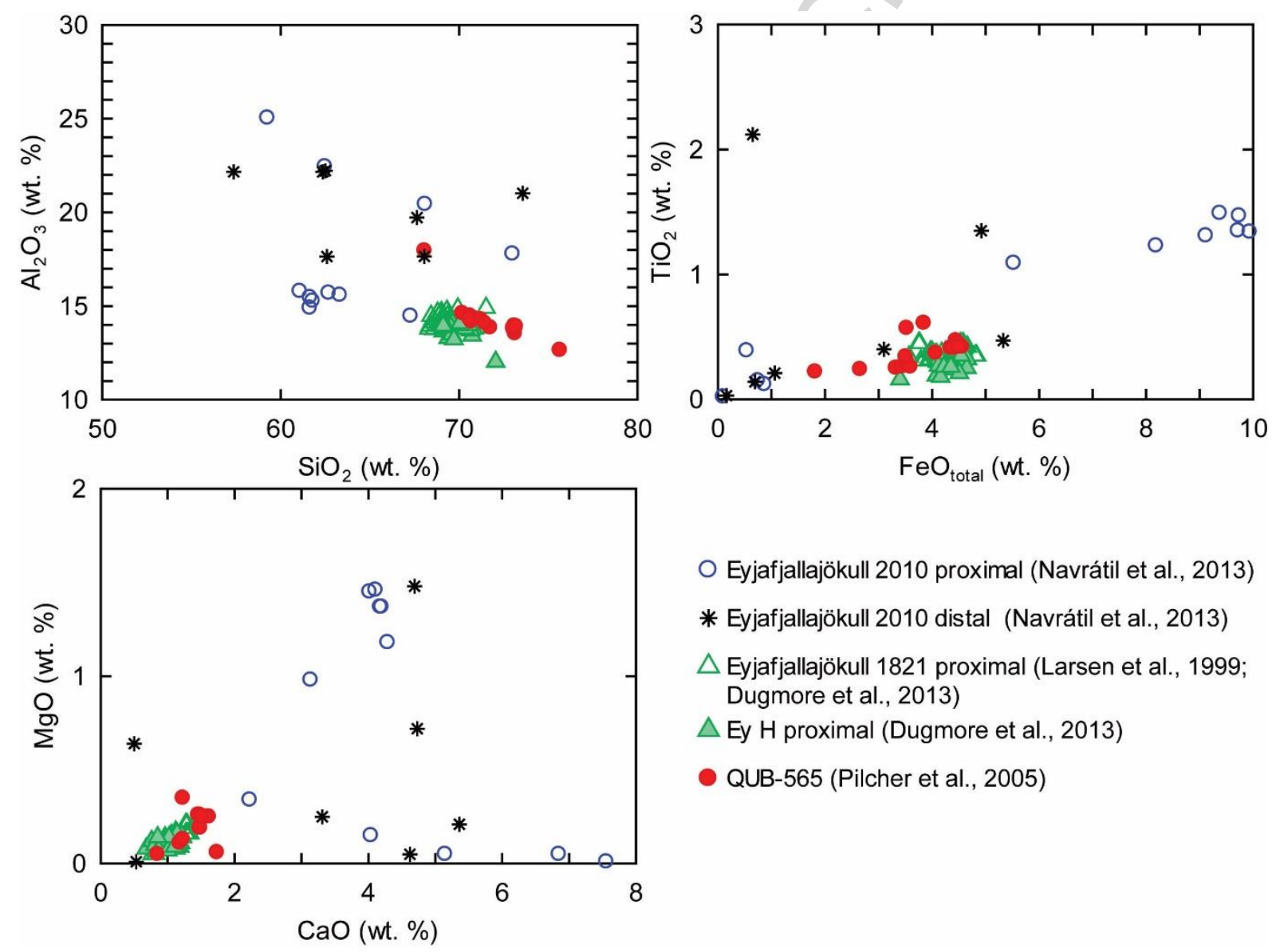

O Eyjafjallajökull 2010 proximal (Navrátil et al., 2013)

* Eyjafjallajökull 2010 distal (Navrátil et al., 2013)

$\triangle$ Eyjafjallajökull 1821 proximal (Larsen et al., 1999; Dugmore et al., 2013)

$\triangle$ Ey H proximal (Dugmore et al., 2013)

- QUB-565 (Pilcher et al., 2005)

Fig. 5. Glass-shard major element compositions of cryptotephra of Eyjafjallajökull 2010

(distal) and QUB-565 compared with glass analyses of proximal Eyjafjallajökull 2010, 1821 and Ey $\mathrm{H}$ tephra. Extensive scatter in the 2010 datasets may be due to instrumental imprecision and/or unwitting analyses of mineral inclusions (microlites).

\subsubsection{Vatnajökull region}


The Vatnajökull ice cap covers a number of volcanic systems, including Grimsvötn, Veidivötn-Bárdarbunga (hereafter referred to as Veidivötn) and Kverkfjöll. All three systems are associated with predominantly basaltic tephras, a small number of which have been identified as cryptotephra. Material from Grimsvötn 1903 and 1783 (Laki) eruptions was found in the Lomonosovfonna ice core, Svalbard (Wastegård and Davies, 2009), the latter also being identified in western Ireland (BRACSH-1: Reilly and Mitchell, 2015). A Grimsvötn cryptotephra of historical age was identified at Claraghmore Lake, Ireland (CLA-L1), and an individual shard was found amongst Öraefajökull 1362 tephra in the adjacent bog (CLA-B1: Watson et al., 2016), in the light of which a possible correlation with 1354 Grimsvötn eruption may be posited. Two shards of Grimsvötn-type tephra were identified in Tiefer See Lake, Germany, dating to 870 CE (Wulf et al., 2016). An older event ( $4000 \mathrm{BCE}$ ) is represented by the Hov tephra recorded in the Faroes (Wastegård 2002).

The basaltic components of the Settlement ( 870s CE) and Veidivötn 1477 tephras are both recorded as cryptotephras. The former reached the Faroes (Wastegård et al., 2001) and northern Britain (Cage et al., 2011), as well as Greenland (Grönvold et al., 1995; Zielinski et al., 1997). The cryptotephra records imply that the two components of the Settlement tephra did not disperse over the same areas in Europe. Veidivötn 1477 had a potentially wider distribution in Europe that extends from Sweden (Davies et al., 2007) to western Ireland (Chambers et al., 2004). Glass shards with a Veidivötn-like composition were also identified at Svartkälsjärn Lake, Sweden (SV-L2: Watson et al., 2016). As the shards were mixed with those of the Hekla 1104 and 1158 CE eruptions, it is possible that they derive from the 1159 CE Veidivötn eruption.

An unidentified source beneath the Vatnajökull ice cap is thought to have recurrently produced a rhyolitic tephra represented locally by SAU-65 (Larsen and Eiríksson, 2008) and tephra horizons at Bláskógar and Eyjafjarđardalur, Iceland (Wastegård et al., 2003). Numerous cryptotephras sharing the same glass composition have been identified in the Late Glacial and Early Holocene (Lind et al., 2016), and are known as the "Borrobol-type tephras" after their initial findspot in Scotland (Pyne-O'Donnell, 2007). SAU-65 correlates with the Microlite tephra ( 700 BCE) identified in Ireland, Britain and Germany (see Supplementary File 2). The AD860A tephra (Pilcher et al., 1996) also shares this rhyolitic 
glass geochemistry, and was erupted $\sim 850 \mathrm{~s} C E$, approximately around the same time Veidivötn and Grimsvötn were active. We identify three further occurrences of this glass composition, mainly found as secondary populations amongst other cryptotephras (Table 1; Fig. 6). Borge-15 occurs with BTD-15 at Borge, Norway (Pilcher et al., 2005), and can similarly be dated to around 1650-1750 CE. GB4-198b is found alongside a Katla silicic cryptotephra (GB4-198a: SILK-N4?) at Garry Bog, Ireland, and has an interpolated age of 1900 BCE. GB4-250b is recorded at a number of sites in Ireland and Norway, mixed in each instance with Hekla tephra (GB4-240a) and stratified below the Hekla 4 unit. Based on its age estimate, a possible correlative may also be present at Whitehorse Hill (WHH-11 47$50 \mathrm{~cm}$ : Fyfe et al., 2016). The Mid- to Late Holocene populations appear to have a more extended geochemical range than their Late Glacial and Early Holocene counterparts, but the partial analyses of mineral inclusions within the glass shards have also introduced considerable scatter into the geochemical results (Fig. 6).
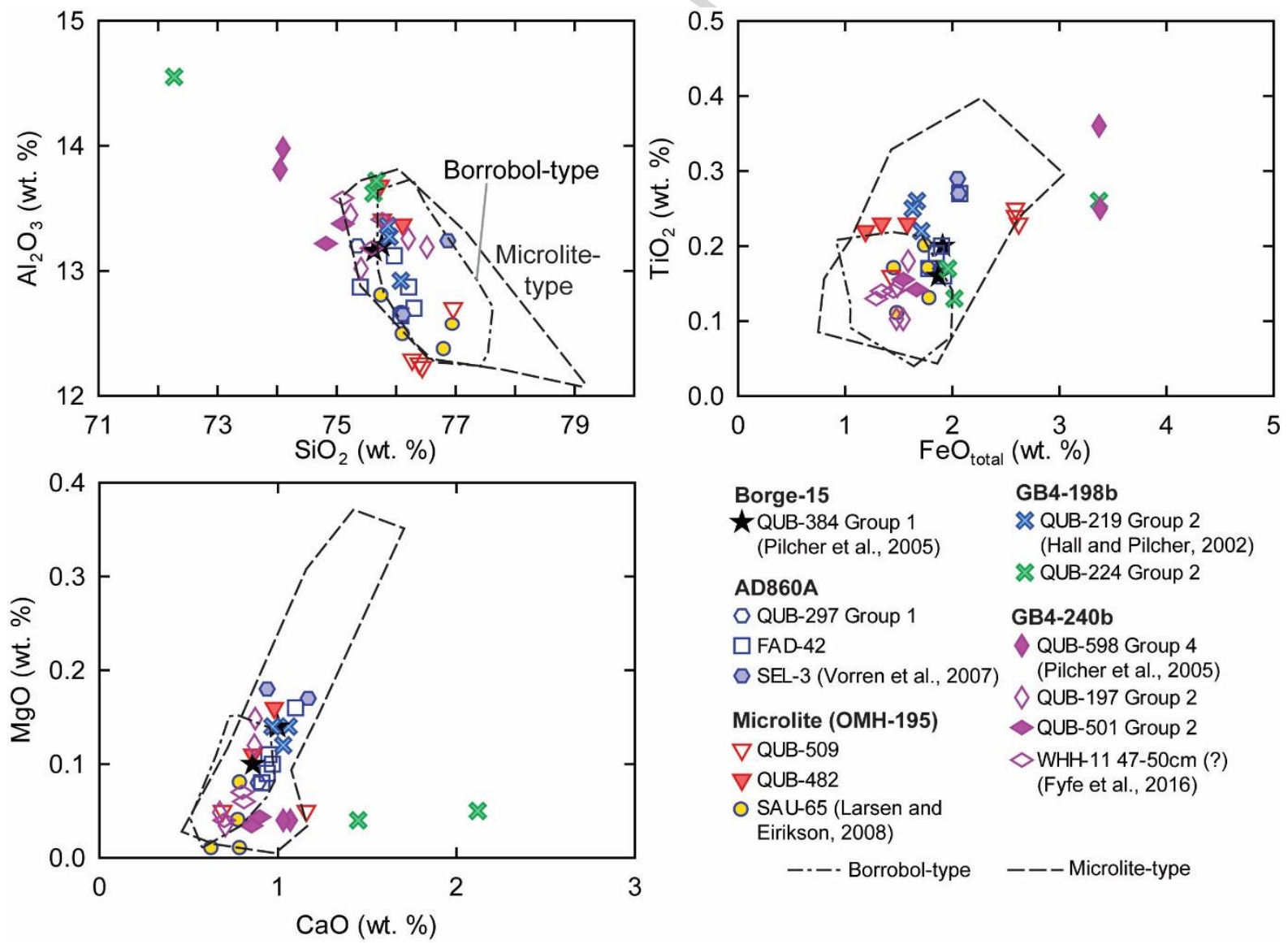

$$
\begin{aligned}
& \text { Borge-15 GB4-198b } \\
& \star \text { QUB-384 Group } 1 \text { \QUB-219 Group } 2 \\
& \text { (Pilcher et al., 2005) (Hall and Pilcher, 2002) } \\
& \text { AD860A } \\
& \text { O QUB-297 Group } 1 \quad \text { GB4-240b } \\
& \square \text { FAD-42 QUB-598 Group } 4 \\
& \text { O SEL-3 (Vorren et al., 2007) (Pilcher et al., 2005) } \\
& \text { Microlite (OMH-195) } \ \text { QUB-197 Group } 2 \\
& \nabla \text { QUB-509 } \\
& \nabla \text { QUB-482 } \\
& \text { O SAU-65 (Larsen and } \\
& \text { Eirikson, 2008) } \\
& \text {--- Borrobol-type } \\
& \diamond \text { WHH-11 47-50cm (?) } \\
& \text { (Fyfe et al., 2016) }
\end{aligned}
$$

Fig. 6. Glass-shard major element compositions of cryptotephras attributed to an unknown source beneath Vatnajökull ice cap in Iceland (all data this paper unless otherwise stated). 
The compositional envelopes for the Late Glacial and Early Holocene Borrobol-like tephras (Borrobol, Penifiler, Fosen, Ssn) are based on data from Turney et al. (1997), Boygle (1999), Pyne-O'Donnell (2007), Pyne-O'Donnell et al. (2008), Gudmundsdóttir et al. (2011) and Lind et al. (2013). The Mid- to Late Holocene populations are typified by the Microlite tephra, the compositional envelopes for which are based on data from Hall and Pilcher (2002), van den Bogaard and Schmincke (2002) and Plunkett et al. (2004).

\subsection{Alaska}

\subsubsection{Churchill}

The AD860B tephra was amongst the first cryptotephras identified in Europe (Pilcher et al., 1996) and has recently been correlated on the basis of its glass composition with the White River Ash eastern lobe (WRAe) attributed to Mount Churchill in eastern Alaska (Jensen et al., 2014). Its distribution extends to northern Scandinavia and Poland (Pilcher et al., 2005; Watson et al., 2017a). Although only one other eruption of Churchill ( 100 CE) has been formally recognised (Siebert et al., 2010), the European distal record shows the presence of geochemically identical glass populations dating to 1600 CE (SLU-5), 1100 CE (SLU-31) and 2350 BCE (the Hall tephra; Table 2; Fig. 2; Supplementary File 2). Multiple Churchill-type tephras have also been reported from North America (Davies et al., 2016), including the Lena tephra (Payne et al., 2008) whose age estimate is similar to that of SLU-5. A slightly younger tephra bed above the proximal WRAe lobe in Canada (Preece et al., 2014) may be a correlative for SLU-31, identified at two peatlands in Ireland. Shards of the oldest of the European Churchill-type tephras, the Hall Tephra, are found mixed with those of Hekla 4 at two sites in the north of Ireland.

We include in our list of AD860B occurrences the unidentified tephra associated with a Snaefellsjökull eruption at Kongressvatnet, Svalbard (D'Andrea et al., 2012). Although it is conceivable that the Kongressvatnet tephra represents the older White River Ash northern lobe (WRAn) erupted in approximately the same time interval as the $\mathrm{Sn}-1$ ash, a younger date for the couplet (cf. Borge tephrostratigraphy, Supplementary File 3) allows for an agemodel for Kongressvatnet that shows a relatively constant peat accumulation at the site before and after the Öraefajökull 1362 horizon at this site. 
Table 2: Cryptotephras of non-Icelandic origin in northwest Europe

\begin{tabular}{|c|c|c|}
\hline Volcanic region & Source & Tephra (age) \\
\hline \multirow[t]{4}{*}{ Alaska } & Churchill & SLU-5 [Lena tephra?] ( 1600-1700 CE), SLU-31 ( 1104 \\
\hline & & CE), AD860B [WRAe] (853 \pm 1 CE), Hall Tephra ( 2350 BCE) \\
\hline & Augustine? & GB4-147 ( 700 BCE) \\
\hline & Aniakchak & GB4-182b [CFE II] ( 1640 BCE) \\
\hline \multirow[t]{4}{*}{ Cascades } & Rainier? & SV-L5 ( 4000-3000 BCE) \\
\hline & Mount St Helens? & SLG-5 [MSH-W?] ( 1480 CE), LLG-274 [MSH-Y?] ( 1800 \\
\hline & & BCE) \\
\hline & Crater Lake & MOR-T12 [Mazama] ( 5350 BCE) \\
\hline \multirow[t]{2}{*}{ Mexico } & Ceboruco & MOR-T4 [Jala Pumice?] ( 1000 CE) \\
\hline & El Chichón? & DOM-3 ( 650 CE), DOM-4 Group 1 ( 400 CE) \\
\hline \multirow[t]{2}{*}{ Kamchatka } & Ksudach & $\mathrm{KS}_{2}(\sim 5250 \mathrm{BCE})$ \\
\hline & Shiveluch & SLU14-60 [SHdv?] ( $\sim 3100 \mathrm{BCE})$ \\
\hline \multirow[t]{3}{*}{ Azores } & Furnas & PMG-5 [Furnas 1630 ?] ( 1600-1700 CE), MOR-T2 [Furnas \\
\hline & & 1441?] ( 1400 CE), MOR-T7 ( 280 CE), MOR-T8 ( 150 \\
\hline & & CE), MOR-T9 ( 35 CE), DCSH-2 ( 400 BCE) \\
\hline Mediterranean & Lipari? & GB4-45a [Monte Pilato?] ( 1300 CE) \\
\hline
\end{tabular}



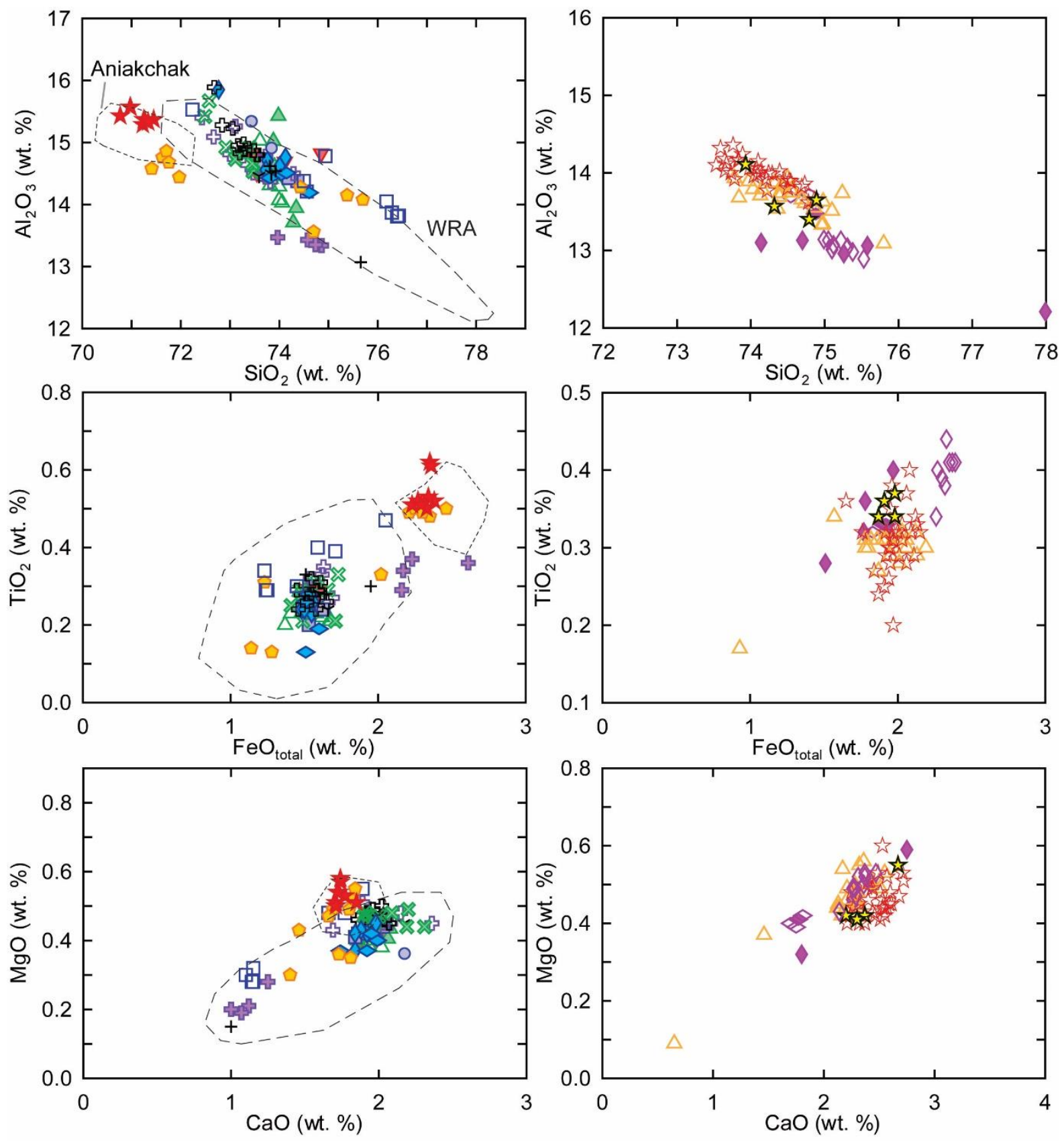

\section{SLU-5 \\ $\nabla$ QUB-122}

SLU-31

$\triangle$ FAL4 (Rea, 2011)

$\triangle$ QUB-118 (Hall and Pilcher, 2002)

Hall Tephra

$\checkmark$ QUB-324 (Doyle, 2003)

$\checkmark$ QUB-505

Aniakchak

NDN-300 (Pyne-O'Donnell et al., 2012)

$\star$ GB4-182b
AD860B

$\square$ Kongress 39-44 cm, Group 1 (D'Andrea et al., 2012)

$\square$ QUB-394 Group 1

+ QUB-448

Y QUB-251 Group 1

њ QUB-453

\& QUB-297 Group 2 (?)

њ QUB-485

O QUB-103 Group 2

$\bowtie$ QUB-478

\QUB-459
Augustine?

$\checkmark$ Augustine (Siebert et al., 1985)

Augustine 1883 (Siebert et al., 1985)

$\checkmark$ Augustine B (Siebert et al., 1985)

$\checkmark$ Augustine C1, C2, H, I, G (means; Tappen et al., 2009)

$\triangle$ NDN-230 (Pyne-O'Donnell et al., 2012)

¿r Ruppert Tephra (Monteath et al., 2017) ฟ $Q$ QUB-490

--- WRA

Aniakchak

Fig. 7. Glass-shard major element compositions of cryptotephras of possible Alaskan origin (all data from this paper unless otherwise stated). Compositional envelopes for White River 
Ash (WRA) are based on data from Preece et al. (2014), and for Aniakchak on Kaufman et al. (2012).

\subsubsection{Augustine?}

A small peak of glass shard concentrations in a cryptotephra in Garry Bog, Ireland, yielded geochemical analyses from a single shard (QUB-490: Plunkett, 1999). The sample has since been re-analysed and the geochemical composition has been replicated from three further shards, supporting its characterisation as a distinct tephra unit (GB4-147; Fig. 7;

Supplementary Table 1). The results are comparable to glass analyses of NDN-230 identified in Nordan's Pond, Newfoundland, where it was tentatively correlated with Augustine Unit G (Pyne-O'Donnell et al., 2012). The GB4-147 glass geochemistry also bears a close resemblance to that of Augustine's younger ( 1450 CE) Unit B (Siebert et al., 1995) and to matrix glass data from several prehistoric Augustine eruptions (Tappen et al., 2009). The interpolated date for GB4-147 is 700 BCE, several centuries earlier than NDN-230 but consistent with the modelled age of RC108 ("Ruppert Tephra") reported from Ruppert Lake, Alaska (Monteath et al., 2017) to which it is also similar. Although the attribution of NDN230 to Augustine $\mathrm{G}$ has been questioned (Mackay et al., 2016), there are too few published data available to refute the correlation with this system entirely. On the basis of the similar glass major element geochemistries, we argue that Augustine remains a potential source for these tephras, but trace element analysis of their glass is required to resolve the correlation.

\subsubsection{Aniakchak}

A notable peak of colourless cryptotephra in Garry Bog, Ireland (GB4-182), was geochemically analysed at different times between April 1993 and May 1997. Each of three samples (QUB-124, -128 and -182) yielded three populations of rhyolitic glass, only one of which - whose source has not yet been identified - has been previously published (Hall and Pilcher, 2002). A second population (GB4-182b) has a geochemical composition that resembles the rhyolitic end member of Aniakchak eruptions (Fig. 7; Kaufman et al., 2012). The third suite (GB4-182c) evidently derives from Hekla. The previous age estimate of this unit at Garry Bog was 1350 BCE (Hall and Pilcher, 2002), based on linear interpolation between the GB4-150 ( 800 BCE) and Hekla 4 ( 2310 BCE) deposits, but a change in peat stratigraphy between the Hekla 4 and GB4-182 levels likely signals a shift in the peat 
accumulation rate at the site (Plunkett, 1999). We propose, therefore, that GB4-182b derives from the Aniakchak Caldera Forming Eruption (CFE II) at 1640 BCE (Bacon et al., 2014), as this tephra has been reported from Nordan's Pond, Newfoundland (PyneO’Donnell et al., 2012), and the NGRIP ice core, Greenland (Coulter et al., 2012), demonstrating its extent as far as the North Atlantic region.

\subsection{Cascades}

\subsubsection{Rainier?}

Watson et al. (2016) identified a cryptotephra (SV-L5) comprising glass shards of unknown source in Svartkälsjärn, Sweden, mixed with two shards of Hekla origin (possibly Hekla 5/Lairg A) and with an estimated age of $\sim 4500-4000$ BCE. The unidentified shards include some datapoints whose geochemistries suggest the presence of mineral inclusions in the analyses, but a core group of medium-Ca ( $\mathrm{CaO} \sim 2.5$ wt. \%) composition lies with the geochemical field of proximal glass from Rainier (Sisson and Vallance, 2009; Samolczyk et al., 2016; Fig. 8). Rainier is known to have erupted frequently during the Holocene, often generating highly destructive lahars, the most notable of which was the Osceola Mudflow 3650 BCE (Vallance and Scott, 1997). Its eruptions have generally been attributed VEIs of 2 or 3 (Siebert et al., 2010), but their magnitudes may have been underestimated as local tephra preservation will have been adversely affected by concurrent and subsequent mudflows. 

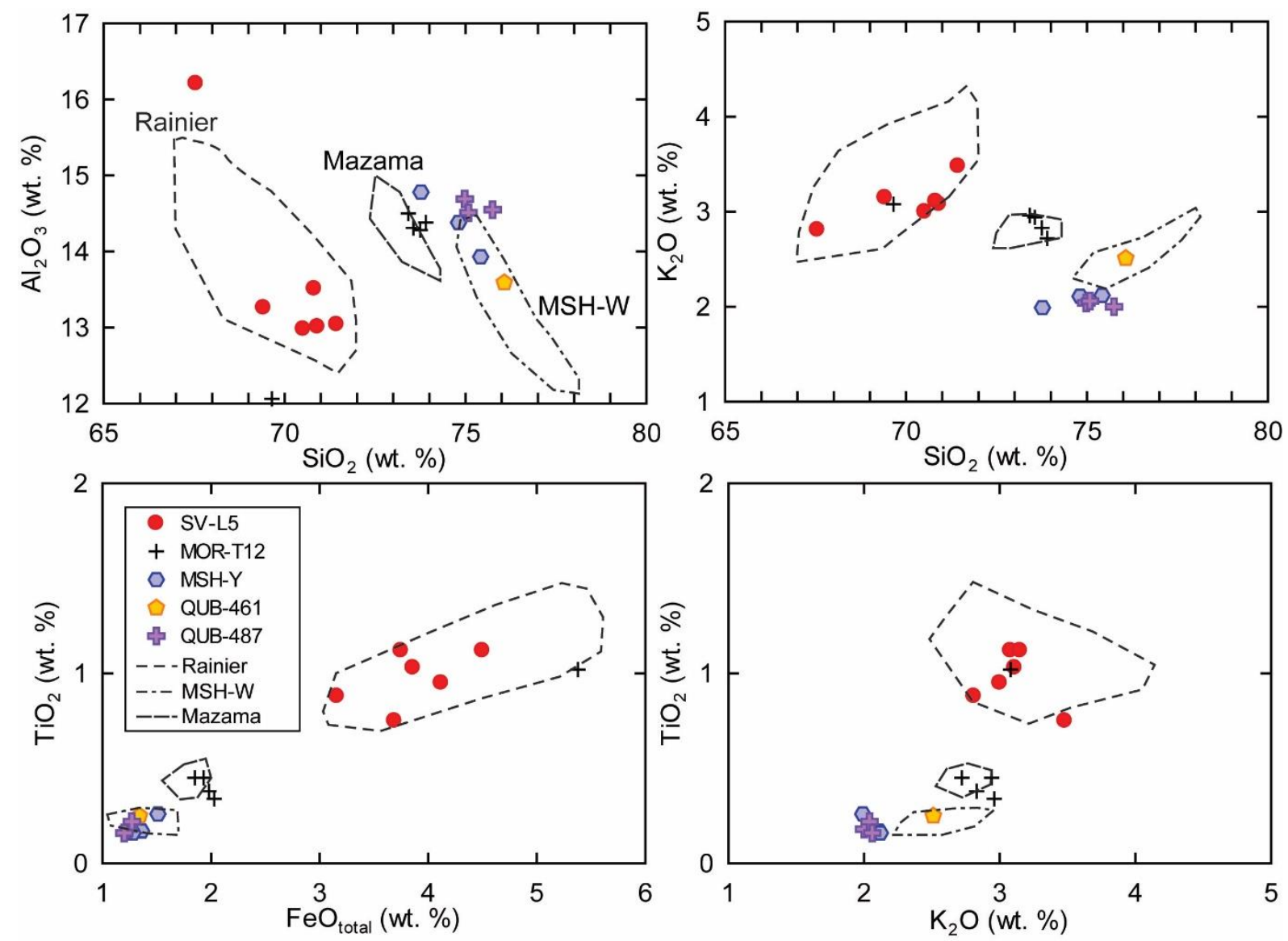

Fig. 8: Glass shard compositions of cryptotephras of possible Cascades origin: MOR-T12 (Chambers et al., 2004); SV-L5 (Watson et al., 2016; QUB-461, -159 Group 3 and -487 (this paper). Compositional envelopes are based on published data (excluding outliers): Rainier

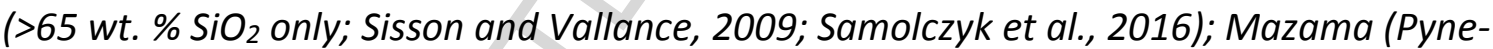
O'Donnell et al., 2012; Egan, 2016); Mount St Helens MSH-W (Pyne-O'Donnell et al., 2012; Mackay et al., 2016). Mean values for glass of Mount St Helens Set Y (Ye, Yn, Yb: Westgate, 1977) are also shown.

\subsubsection{Mount St Helens?}

A minor tephra deposit with an extrapolated age of 1800 BCE in Lough Lurgeen, Ireland (LLG-274), comprised small, silicic shards (Plunkett, 1999). Microprobe analyses were possible on only three shards but their major element composition is consistent and shows an affinity with material from Mount St Helens (Fig. 8). In view of its age estimate, a possible correlation with MSH Set $\mathrm{Y}$ is proposed, specifically with unit $\mathrm{Yn}$, the most voluminous Holocene eruption at this source, or the slightly younger unit Ye, whose ash was dispersed eastwards (Carey et al., 1995). Tephrostratigraphies in other bogs in the west of Ireland 
suggest that this unit may be regionally represented (Plunkett, 1999). Further investigations are warranted to enable a firmer characterisation of this cryptotephra.

A tentative representation (SLG-5) of Mount St Helens tephra in Ireland is also suggested by sparse shards mixed with Hekla 1510 populations at Sluggan Bog (QUB-486 outlier) and Owenbeg (QUB-159 Group 1; Fig. 8). Its age ( 1500 CE) implies that it may correlate with Mount St Helens Set Wn ( 1479 CE) or Set We ( 1482 CE) (Yamaguchi, 1983; 1985). Cryptotephra attributed to Set We has been identified in eastern Canada (Pyne-O'Donnell et al., 2012; Mackay et al., 2016), and its presence along the northeastern Atlantic seaboard is not therefore unexpected. Attempts to obtain additional analyses from the Irish samples or to isolate this cryptotephra at other sites have been hampered by the dominance of Icelandic cryptotephras in Irish sedimentary sequences around this time.

\subsubsection{Crater Lake}

Chambers et al. (2004) reported two cryptotephras whose glass geochemistry resembled that of Hekla 5/Lairg A, but the lower of the two, MOR-T12, has an interpolated age estimate of $\sim 5300$ cal yr BCE, and is thus older than Lairg A. We find that the normalised geochemical data for the MOR-T12 glass are distinct from those of Hekla tephra, having clearly higher $\mathrm{TiO}_{2}$ and $\mathrm{MgO}$ abundances. Instead we identify a striking affinity with glass analyses of the Mazama tephra, dated to 5700 BCE (Fig. 8; Egan et al., 2015). Mazama tephra has been identified at Nordan's Pond, Newfoundland (Pyne-O'Donnell et al., 2014), and a similar glass has been reported from the GISP2 ice core, Greenland (Zdanowicz et al., 1999). Given the large magnitude of this eruption, it is not surprising that its tephra reached Europe but its representation remains restricted for the time being to An Loch Mór, western Ireland.

\subsection{Mexico}

\subsubsection{Ceboruco}

A small number of analyses of shards in a mixed deposit at Faddanmore, Ireland (FAD-30), show geochemical correspondence with glasses of the rhyolitic end member of the Jala Pumice tephra from Ceboruco, Mexico (Gardner and Tait, 2000; Fig. 9) that has been dated to 990-1020 CE (Sieron and Siebe, 2008). Cryptotephra attributed to this eruption has 
recently been identified in northeast America (Mackay et al., 2016), suggesting its widespread distribution. Other shards in the Faddanmore unit correspond to the geochemically-distinct MOR-T4 tephra, whose source until now was suspected to be Iceland (Chambers et al., 2004), which has been found at several sites in Ireland and Wales (see Supplementary File 2). This population is similar to the dacitic end-member (with a trachydacitic glass composition) of the Jala Pumice (Gardner and Tait, 2000), although few glass-based major element data are available for comparison. The immediate association of the two populations in the Faddanmore unit prompts us to correlate the MOR-T4 tephra with the Jala Pumice (Gardner and Tait, 2000; Chertkoff and Gardner, 2004).
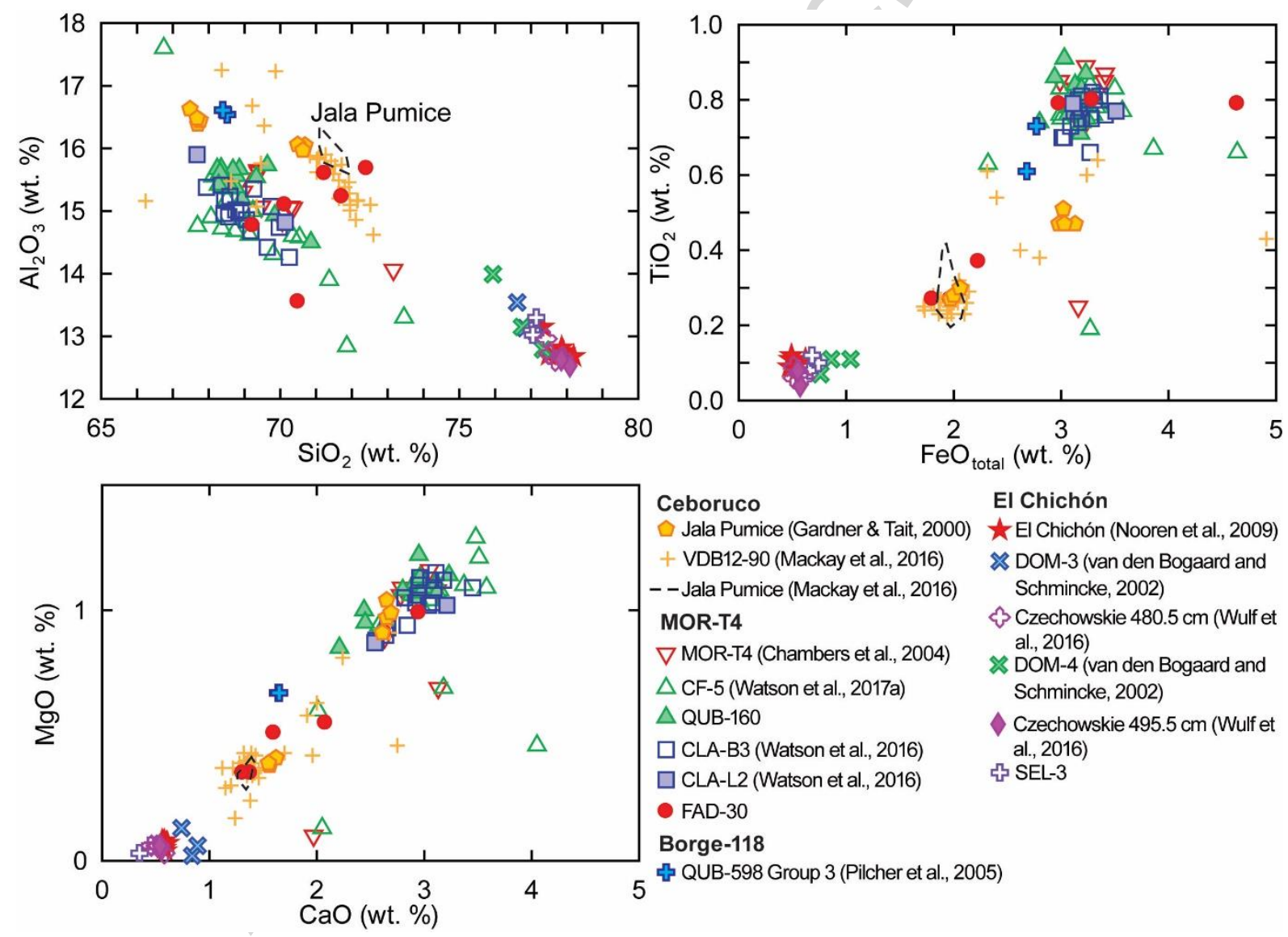

Ceboruco El Chichón

$\checkmark$ Jala Pumice (Gardner \& Tait, 2000) \ El Chichón (Nooren et al., 2009)

+ VDB12-90 (Mackay et al., 2016) « DOM-3 (van den Bogaard and

- - Jala Pumice (Mackay et al., 2016)

Schmincke, 2002)

MOR-T4

$\nabla$ MOR-T4 (Chambers et al., 2004)

\& Czechowskie $480.5 \mathrm{~cm}$ (Wulf et al., 2016)

$\triangle$ CF-5 (Watson et al., 2017a)

\OM-4 (van den Bogaard and Schmincke, 2002)

$\triangle$ QUB-160

$\square$ CLA-B3 (Watson et al., 2016)

$\square$ CLA-L2 (Watson et al., 2016)

$\checkmark$ Czechowskie $495.5 \mathrm{~cm}$ (Wulf et al., 2016)

- FAD-30

Borge-118

\& QUB-598 Group 3 (Pilcher et al., 2005)

Fig. 9. Glass compositional analyses of cryptotephra attributable the Jala Pumice, Ceboruco, and possibly El Chichón. Compositional envelopes for Jala Pumice are based on proximal data from Mackay et al. (2016). Also shown is the unidentified Borge-118 tephra whose glass major element geochemistry shares a similar composition to that of the Jala Pumice.

\subsubsection{El Chichón?}


Tentative correlations with eruptives from El Chichón are two tephras first identified in Germany (van den Bogaard and Schmincke, 2002) where they were dubbed DOM-3 ( 650 CE) and DOM-4 ( 400 CE). Both deposits were poorly characterised by only a small number of constituent glass analyses and DOM-4 also includes shards attributable to Hekla. The distinctively low $\mathrm{CaO}$ and $\mathrm{FeO}_{\text {total }}$ rhyolitic glass-shard populations seen in both units (Fig. 9) have since been identified in Poland (Wulf et al., 2016) and perhaps in Norway (Vorren et al., 2007). The glass major element composition bears some resemblance to that of the recurrent Borrobol-type material from the Vatnajökull centre but the glasses are clearly distinguishable by the $\mathrm{FeO}_{\text {total }}$ to $\mathrm{K}_{2} \mathrm{O}$ ratios. Similar glass has been reported from eruptives of El Chichón, Mexico (Nooren et al., 2009), and Opala, Kamchatka (Kyle et al., 2011;

Plunkett et al., 2015). The $\mathrm{Cl}$ content ( $\geq 0.1$ wt. \%) of the cryptotephras favours El Chichón as the more likely source. Furthermore, only one eruption of Opala is known to have occurred in this timeframe (Braitseva et al., 1997; Kyle et al., 2011) whereas El Chichón was more frequently active, with Units $F$ and E erupted at $\sim 335 \pm 85 \mathrm{CE}$ and $\sim 567 \pm 37 \mathrm{CE}$, respectively (Nooren et al., 2009). Trace element analyses of the glasses of the cryptotephras are required to confirm their correlation.

\subsection{Kamchatka}

3.5.1. Ksudach

The recognition of Ksudach $\mathrm{KS}_{2}$ (5350-5210 BCE, Plunkett et al. 2015) ash in Svalbard (van der Bilt et al., 2017) marks the first formal identification of a tephra from the most active volcanic region in the Northern Hemisphere. Its younger ( $200 \mathrm{CE})$ and more voluminous counterpart, $\mathrm{KS}_{1}$, is known to have reached Nova Scotia (Mackay et al., 2016) but has not yet been identified in Europe. Both tephras were produced by caldera-forming eruptions that were, in volumetric terms, amongst the largest Kamchatkan eruptions during the Holocene.

\subsubsection{Shiveluch}

Tephra with vesicular glass (SLU14-60) from Sluggan Bog, Ireland, dating to 3000 BCE (Supplementary File 3) shows a strong geochemical affinity with glass of Shiveluch proximal material, most closely matching the rhyolitic end-member of SHdv (SH unit 34) of a similar age (Ponomareva et al., 2015; Fig. 10). Shiveluch is one of Kamchatka's most active 
volcanoes and has produced many large magnitude eruptions during the Holocene. Its volcanic history has been well-constrained through detailed proximal records (Ponomareva et al., 2015), but many of its tephra beds share similar major element glass compositions which complicates the correlation of distal ash deposits to discrete events. To the best of our knowledge, this is the first extra-regional report of a Shiveluch tephra.
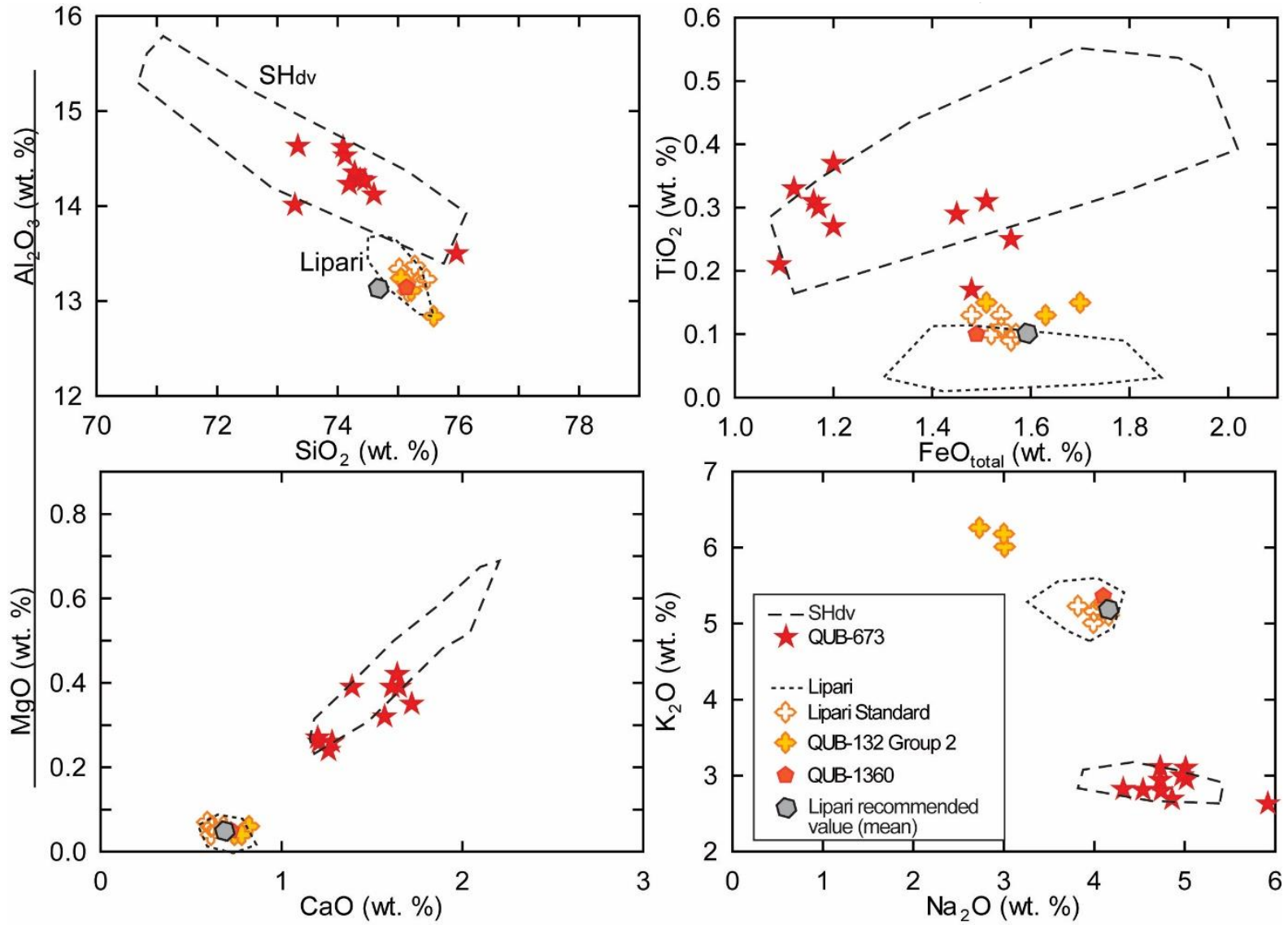

Fig. 10. Glass major element analyses of cryptotephras attributable to Shiveluch, Kamchatka, and possibly Lipari, Italy. Compositional envelopes for the SHdv (SH unit 34) glass are based on data from Bourgeois et al. (2006), Kyle et al. (2011), Ponomareva et al. (2015; 2017) and for Lipari on Bescoby et al. (2008) and Albert et al. (2012). Secondary glass standard measurements on Lipari reference material, measured with QUB-132, are also shown, as well as its mean recommended value (normalised; Kuehn et al., 2011).

\subsection{Azores}

3.6.1. Furnas 
Recent investigations of proximal tephras on the Azores have enabled the characterisation of glass from the main volcanic centres in these islands (Johansson et al., 2017). Constituent glass compositions are trachybasaltic to trachytic, and differentiable to individual sources but perhaps not to specific eruptions. The Furnas 1630 tephra shows a strong affinity with a number of cryptotephra deposits identified in Ireland on the basis of glass major element compositions. The PMG-5 tephra identified in central and southwestern Ireland (Hall and Pilcher, 2002) has an interpolated date of $1600 \mathrm{CE}$, possibly concurrent therefore with the Furnas 1630 eruption. A geochemically identical unit (MOR-T2) was subsequently identified in a stratified position below the Veidivötn 1477 cryptotephra at An Loch Mór, western Ireland, where it has an interpolated age of 1400 CE (Chambers et al., 2004), closely matching an early historic eruption of 1441 CE. Further cryptotephras sharing the same glass-based geochemical composition were also identified and dated by interpolation to 280 CE (MOR-T7), 150 CE (MOR-T8) and 35 CE (MOR-T9) at An Loch Mór (Chambers et al., 2004), and to 415 BCE at Derrycunihy Wood (Reilly and Mitchell, 2015), at least three of which have counterparts in proximal deposits at Furnas. The cryptotephras are mainly concentrated in western Ireland but an individual shard at Cors Fuchno, Wales (Watson et al., 2017a), possibly corresponds with the MOR-T2 tephra. Their distribution suggests that they may be present in more southerly regions of Atlantic Europe.

\subsection{Mediterranean}

\subsubsection{Lipari?}

Shards with a geochemical composition similar to that of the Lipari Monte Pilato tephra have been identified in Garry Bog, Ireland (GB4-45a; Fig. 10). Alkali values are, however, discrepant, with elevated $\mathrm{K}_{2} \mathrm{O}$ and lower $\mathrm{Na}_{2} \mathrm{O}$ abundances that, along with the lower analytical totals (mean $=95.76 \mathrm{wt} \%$ ) relative to the Lipari secondary glass standard (mean $99.49 \mathrm{wt} \%)$ that was analysed simultaneously, might reflect alteration of the glass. Constrained between the Öraefajökull 1362 and Hekla 1158 tephras at this site, GB4-45a has an interpolated age of 1300 CE. A comparable tephra (QUB-1360) was noted in Greenland ice where it is dated to $1254 \mathrm{CE}$, although only one shard was analysable (Coulter et al., 2012). Nevertheless, the dates for these two tephras are consistent with the mid-13th century Lipari eruption which has only recently been recognised as a distinct unit through archaeomagnetic dating (Arrighi et al., 2006). The event is not recorded historically. 
Further attempts to locate this cryptotephra in Irish bogs is ongoing, but isolating it is complicated by the many eruptions contributing ash to Europe around this time.

\subsection{Unknown}

Three tephra deposits remain whose sources cannot be identified. GB4-182a, identified at Garry Bog, Ireland, bears some compositional resemblance to the glass of Aniakchak tephra with which it is mixed, but has a notably lower $\mathrm{K}_{2} \mathrm{O}$ content. Borge-118, from Borge, Norway (Pilcher et al., 2005), comprises two glass analyses within a mixed population of glass containing shards of Hekla and Vatnajökull tephras dating to 2650 BCE. Its composition bears a slight resemblance to glass of the Jala Pumice tephra of Ceboruco (Fig. 9). Borge133, also from Borge (Pilcher et al., 2005) and with an interpolated age of $3100 \mathrm{BCE}$, is a rhyolitic glass with a $\mathrm{Ti}_{2} \mathrm{O}$ to $\mathrm{CaO}$ ratio that distinguishes it from all other glass analyses in our database.

\subsection{Discussion}

The rapidly growing number of cryptotephra records from northwest Europe has shed considerable light on the frequency of volcanic ash clouds over the region during the Mid- to Late Holocene (Swindles et al., 2011; Watson et al., 2017b). The total number of events $(n=90)$ we identify here is comparable to that reported by Watson et al. (2017b; $n=84)$ for a similar time span, but we have consolidated the record through the recognition of bi- and multi-modal populations, and the cross-correlation of cryptotephras between sites using both major element analyses of glass shards and age and stratigraphic (superpositioning) considerations. Furthermore, we have added 20 cryptotephras to the catalogue, including 16 that have not previously been reported. Notably, only three cryptotephras in our record remain unprovenanced, although further work is required to confirm the suggested attributions of some of the others, notably those of potential Cascades, El Chichón and Lipari origin, as well as a number of possible Katla populations. Our review of the data reveals a considerably wider source area for tephras reaching Europe than has previously been acknowledged (Figs 1, 11). We attribute the success of our re-evaluation to the growing number of published point datasets on glass-based major element compositions 
and to fruitful collaborations between tephrochronologists working in different regions that has facilitated greater knowledge exchange. A paucity of published glass compositional data for many volcanic regions, and a bias towards the study of more voluminous volcanic events, remains an impediment to the successful linkage of cryptotephras to source.

Not surprisingly, Iceland is the main source of cryptotephra in northwest Europe, but almost a quarter of the events we record are derived from other volcanic regions, ranging from southern Europe, Mexico to Kamchatka. Further research is necessary to confirm whether or not GB4-45a is indeed from Lipari, Italy, and to establish better its relationship to the QUB-1360 tephra in NGRIP (Coulter et al., 2012). Tephra from Furnas, Azores, appears to have reached Ireland rather frequently; such a distribution clearly opens up the possibility of finding cryptotephras in French and Iberian sedimentary records. We recognise for the first time the presence of Mexican tephra in Europe, from the large magnitude eruption of Ceboruco and possibly from two eruptions of El Chichón. Like those from Furnas, the Ceboruco tephra's distribution is concentrated in western Ireland. Possible El Chichón tephra, on the other hand, appears to have travelled farther inland and north to Germany and possibly Scandinavia. Tephra dispersal from these eruptions may have been aided by the dominant westerlies coming in from the Atlantic, and it is perhaps surprising that tephras from other large eruptions in Mexico and the Lesser Antilles are not more frequently detected in Europe. Ash from some north Pacific volcanic centres evidently has a greater reach, with Churchill tephra, namely the AD860B deposit, extending to at least Poland (Watson et al., 2017a) and Ksudach tephra to Svalbard (van der Bilt et al., 2017). Other sources, including the Cascades and the Aleutian Arc, are currently represented only in a small number of records, but have perhaps passed unreported due to difficulties in analysing the associated glass, for reasons such as low shard concentrations, small shard size or the presence of mineral inclusions. The wide-ranging source areas of ash revealed in the northwest European cryptotephra records highlight that the risks posed to North Atlantic and European flightpaths by ash clouds are not confined to those emanating from Icelandic eruptions. The diversity of sources may also explain why Ireland records a higher than expected number of ashfall events than would be expected from Iceland alone (Lawson et al., 2012), its position and climate rendering it favourable for capturing transatlantic tephra. 


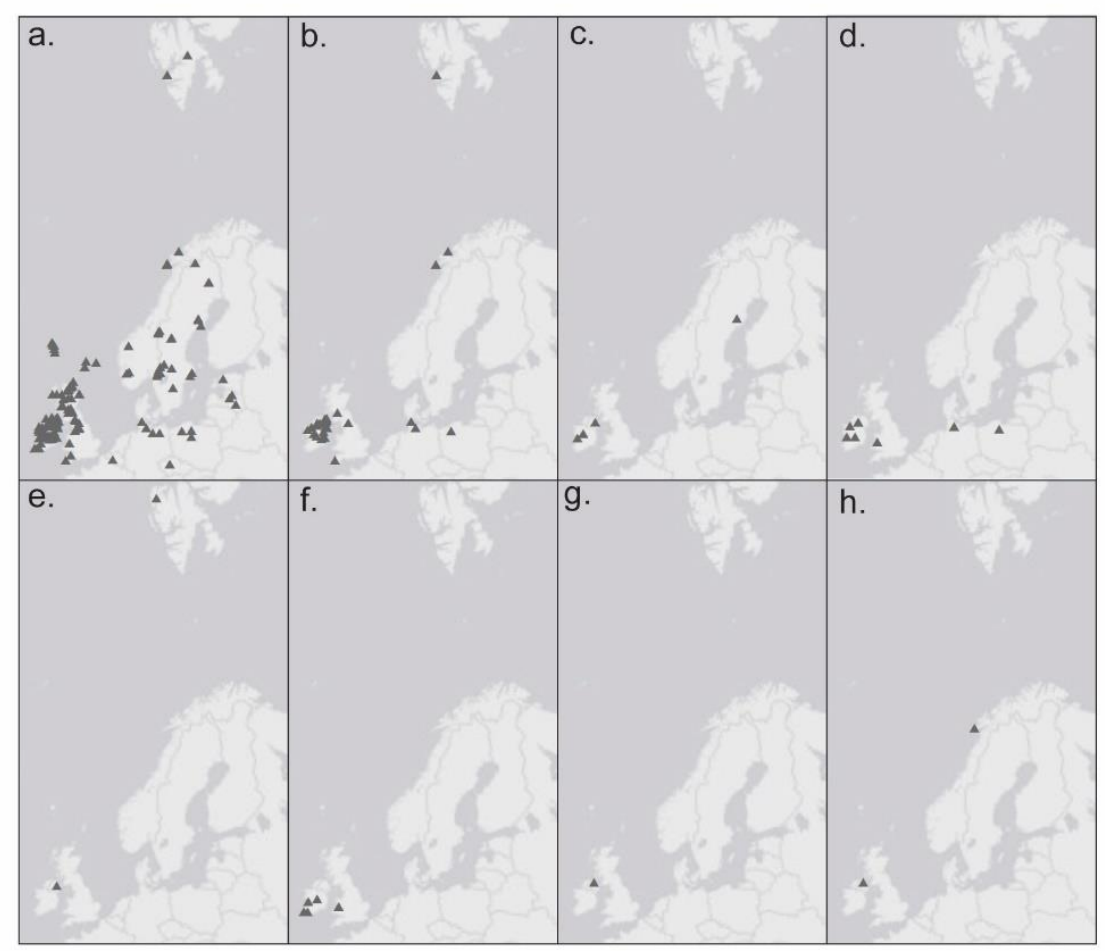

Fig. 11. Locations of northwest European sites containing cryptotephras from, or possibly from, a) (celand; b) Alaska; c) Cascades; d) Mexico; e) Kamchatka; f) Azores; g) Mediterranean; and h) unknown sources.

In addition to the sourcing of non-Icelandic cryptephras, we identify a greater occurrence of ash from Icelandic volcanoes than previously recognised, in particular from Hekla and Katla. All of Hekla's very large magnitude eruptions (VEI 5) and most of its large (VEI 4) events find representation in the distal cryptotephra records in Europe, especially in Scandinavia and Ireland, but as many as eight cryptotephras seem to derive from eruptions that are unknown, or whose magnitudes have not been determined (Siebert et al., 2010), or both. Interestingly, we record a greater frequency of Hekla rhyolitic glass than reported from Iceland (Larsen and Thorarinsson, 1977), notably in the later first millennium CE, and before and after the Hekla 4 event. Similarly, we reveal as many as 12 silicic Katla events, five of which may correspond with the SILK tephras reported in Iceland (Larsen et al., 2001) but seven of which are additions to the record. These additions include the GA4-85 that is widespread in Ireland and the BTD-15 tephra so far identified in Norway and Britain, both more recent than the youngest SILK tephra. Furthermore, we identify glass major element 
compositions that lie between those identified locally, which may inform the understanding of magma evolution prior to eruptions (Óladóttir et al., 2008). While we recognise for the first time cryptotephra from the mid-first millennium CE Eyjafjallajökull eruption in Norway, this source does not appear to have been a frequent producer of widespread ash prior to its 2010 eruption. We extend the volcanic history of Snaefellsjökull to include two events more recent than its $\sim 150$ CE (Sn-1) eruption, namely at $\sim 1300 \mathrm{CE}$ and $\sim 950 \mathrm{CE}$. The dating of these tephras is facilitated in the distal record by their stratigraphic relationships to other well-dated tephras. The Sn-1 tephra, on the other hand, has not yet certainly been observed in northwest Europe, contrary to some suggested correlations (D'Andrea et al., 2012; Watson et al., 2016). The cryptotephra record also increases the number of reported eruptions from Askja, Torfajökull and an unknown source beneath the Vatnajökull ice cap, and clearly highlights the partial nature of proximal tephrostratigraphies as records of past volcanism. Basaltic tephras from Iceland continue to be underrepresented in the distal records, but a small number of cryptotephras from Grímsvötn and Veidivötn are now known.

The Icelandic cryptotephra record draws attention to some potential limitations and pitfalls in the application of tephrochronology in northwest Europe. Several units comprises glasses whose major element geochemistries are indistinguishable, restricting their use as unique isochrons in the absence of other compositional (e.g. trace element) or dating information. The "Borrobol-type" cryptotephra (Lind et al., 2016) from a source beneath the Vatnajökull ice cap, for example, can be found repeatedly throughout the Holocene, but cannot be differentiated to specific events and has therefore limited value as an isochron without additional chronological control. Its AD860A manifestation, however, can help to distinguish the AD860B cryptotephra from other Churchill tephras, if the two are found together as they sometimes are in Ireland. We urge caution too in the interpretation of Hekla, Katla and other Icelandic tephras whose glass compositions may be less unique or infrequent than previously thought.

Watson et al. (2017b) found that eruptions with a VEI $\geq 4$ were the main sources of ash clouds over Europe. With the exception of the events that have not been assigned a VEI rating, the majority of tephras that we identify indeed appear to have been from eruptions 
of such magnitude. A VEI rating is, however, determined using parameters such as cloud height, explosivity and volume of products, and there remains a great deal of uncertainty in the assignations (Siebert et al., 2010). In light of our findings, the eruption magnitude of the seemingly smaller or unassigned events may warrant re-evaluation. Nevertheless, it is possible (even likely) that moderate Icelandic eruptions dispersed tephra towards Europe. Stevenson et al. (2013) indicated that ash reaching the UK from the 2011 Grímsvötn eruption derived from the lower portion (up to $4 \mathrm{~km}$ above sea level) of the plume, from a height attainable by VEI 2 and 3 eruptions. In contrast, it seems that only large (VEI $\geq 5$ ) events from more distant sources, with the exception perhaps of the Azores and a possible Rainier eruption, had the energy and/or tephra volume to generate far-travelled ash clouds. Clearly, as only a small number of VEI $\geq 5$ eruptions are represented in the northwest European cryptotephra record, meteorological conditions remain a leading factor in determining whether or not tephra reached the region. Notable absences in the cryptotephra catalogue are Vesuvius 79 CE, Santorini 1600 BCE, Katmai (Novarupta) 1912 CE, Okmok 100 BCE and Changbaishan (Millennium Eruption) 946 CE, all VEI $\geq 6$ eruptions within what we here regard as the potential tephra catchment of northwest Europe. Ash from Katmai 1912 and the Millennium Eruption has, however, been recorded in Greenland ice cores (Coulter et al., 2012; Sun et al., 2014) and may yet be identified in north European sediments.

\subsection{Conclusions}

We present 90 Mid- to Late Holocene cryptotephras so far identified in northwest Europe and demonstrate that they derive from at least six volcanic regions in the northern hemisphere: Iceland, Azores, Mexico, Cascades, Alaska, Kamchatka and possibly also the Mediterranean. In light of the identification of Chinese and Japanese cryptotephra in eastern North America and in Greenland (Sun et al., 2014; Mackay et al., 2016), we propose that the potential source region for northwest Europe extends to all major volcanic provenances in the northern mid- to high latitudes, as well as tropical North America, that are capable of explosive volcanism. While ash from Icelandic eruptions of moderate magnitude may extend over Europe, ultra-distal transport of tephra seems mainly limited to very large eruptions ( $\mathrm{VEI} \geq 5$ ), and then only subject to suitable meteorological conditions. The recognition of non-Icelandic cryptotephras in Europe highlights the potential to isolate 
them over very large regions, including areas in which cryptotephra studies have not previously been trialled. Notwithstanding the relative infrequency of these events, the ultradistal cryptotephras will greatly facilitate the correlation and comparison of palaeoenvironmental records at intra- and intercontinental spatial scales.

The cryptotephra record in Europe also contributes to the understanding of volcanic history of several Icelandic sources, revealing as it does a greater frequency of explosive eruptions than has been reported. In particular, silicic tephras from Hekla and Katla are recurrent features of the distal record. While it is possible that an eruption could expel ash from a previous event from its conduit, or that strong winds resuspended and transported tephra from terrestrial deposits (e.g. Liu et al., 2014), such phenomena are unlikely to explain all of the unexpected silicic cryptotephra deposits that are found in northwest Europe, particularly when they are replicated at two or more sites and are represented by robust glass-shard analytical datasets. Similarly, repeated cryptotephras with Mount Churchill-type glass-shard major element compositions are recorded in Europe, supporting a growing body of evidence (e.g. Davies et al., 2016) that this system was more active in the Late Holocene than its proximal record indicates. The cryptotephras therefore provide a valuable complement to research on proximal volcanic deposits, recording past eruptions and endmembers that for a variety of taphonomic reasons may not have been preserved locally. 


\section{Acknowledgments}

This research stems in part from a paper presented by GP at the "Tephra 2014" workshop, Portland, USA, attendance at which was part-subsidised by the National Science Foundation (USA). AMS ${ }^{14} \mathrm{C}$ dates to determine the age of the SLU14-60 tephra were supported by the ${ }^{14}$ Chrono Centre, Queen's University Belfast. We are grateful to Siobhan McDermott for producing the distribution maps. We thank David Lowe and an anonymous reviewer for their constructive comments that have helped improve the manuscript. We dedicate this paper to our late friend and colleague, Valerie Hall, a pioneer in European cryptotephra studies and whose work is included in the new material we present.

\section{Funding}

This research did not receive any specific grant from funding agencies in the public, commercial, or not-for-profit sectors. 


\section{References}

Albert, P.G., Tomlinson, E.L., Smith, V.C., Di Roberto, A., Todman, A., Rosi, M., Marani, M., Muller, W., Menzies, M.A., 2012. Marine-continental tephra correlations: volcanic glass geochemistry from the Marsili Basin and the Aeolian Islands, Southern Tyrrhenian Sea, Italy. J. Volcanology Geotherm. Res. 229, 74-94. doi: 10.1016/j.jvolgeores.2012.03.009 Arrighi, S., Tanguy, J.C., Rosi, M., 2006. Eruptions of the last 2200 years at Vulcano and Vulcanello (Aeolian Islands, Italy) dated by high-accuracy archeomagnetism. Phys. Earth Planet. Interiors 159, 225-233. doi: 10.1016/j.pepi.2006.07.010

Bacon, C.R., Neal, C.A., Miller, T.P., McGimsey, R.G., Nye, C.J., 2014. Postglacial eruptive history, geochemistry, and recent seismicity of Aniakchak volcano, Alaska Peninsula (Professional Paper No. 1810). US Geological Survey, Virginia. doi: 10.3133/pp1810 Baillie, M.G.L., Munro, M.A.R., 1988. Irish tree rings, Santorini and volcanic dust veils. Nature 332, 344-346. doi: 10.1038/332344a0

Barber, K., Langdon, P., Blundell, A., 2008. Dating the Glen Garry tephra: a widespread lateHolocene marker horizon in the peatlands of northern Britain. Holocene 18, 31-43. doi: $10.1177 / 0959683607085594$

Bescoby, D., Barclay, J., Andrews, J., 2008. Saints and sinners: a tephrochronology for Late Antique landscape change in Epirus from the eruptive history of Lipari, Aeolian Islands. J. Archaeol. Sci. 35, 2574-2579. doi: 10.1016/j.jas.2008.04.013

Björck, S., Wastegård, S., 1999. Climate oscillations and tephrochronology in eastern middle Sweden during the last glacial-interglacial transition. J. Quat. Sci. 14, 399-410. doi: 10.1002/(SICI)1099-1417(199908)14:5<399::AID-JQS448>3.0.CO;2-R Blockley, S.P., Bourne, A.J., Brauer, A., Davies, S.M., Hardiman, M., Harding, P.R., Lane, C.S., MacLeod, A., Matthews, I.P., Pyne-O’Donnell, S.D., Rasmussen, S.O., Wulf, S., Zanchetta, G., 2014. Tephrochronology and the extended INTIMATE (Integration of Ice-core, Marine and Terrestrial Records) event stratigraphy 8-128 ka b2k. Quat. Sci. Rev. 106, 88-100. doi: 10.1016/j.quascirev.2014.11.002

Borgmark, A., Wastegård, S., 2008. Regional and local patterns of peat humification in three raised peat bogs in Värmland, south-central Sweden. GFF 130, 161-176. doi: $\underline{10.1080 / 11035890809453231}$ 
Bourgeois, J., Pinegina, T.K., Ponomareva, V., Zaretskaia, N., 2006. Holocene tsunamis in the southwestern Bering Sea, Russian Far East, and their tectonic implications. Geol. Soc. Am. Bull. 118, 449-463. doi: 10.1130/B25726.1

Boygle, J.E., 1994. Tephra in Lake Sediments: An Unambiguous Geochronological Marker? Unpubl. PhD Thesis, University of Edinburgh, Edinburgh.

Boygle, J., 1998. A little goes a long way: discovery of a new mid-Holocene tephra in Sweden. Boreas 27, 195-199. doi: 10.1111/j.1502-3885.1998.tb00878.x

Braitseva, O.A., Ponomareva, V.V., Sulershitsky, L.D., Melekestev, I.V., Bailey, J., 1997. Holocene key-marker layers in Kamchatka, Russia. Quat. Res. 47, 125-139. doi: 10.1006/qres.1996.1876

Büntgen, U., Eggertsson, Ó., Wacker, L., Sigl, M., Ljungqvist, F.C., Di Cosmo, N., Plunkett, G., Krusic, P.J., Newfield, T.P., Esper, J., Lane, C., Reinig, F., Oppenheimer, C., 2017. Multi-proxy dating of Iceland's major pre-settlement Katla eruption to 822-823 CE. Geol. 45, 783-786. doi: $\underline{10.1130 / G 39269.1}$

Cage, A.G., Davies, S.M., Wastegård, S., Austin, W.E., 2011. Identification of the Icelandic Landnám tephra (AD 871 2 ) in Scottish fjordic sediment. Quat. Int. 246, 168-176. doi: $\underline{10.1016 / \text { i.quaint.2011.08.016 }}$

Carey, S., Gardner, J., Sigurdsson, H., 1995. The intensity and magnitude of Holocene plinian eruptions from Mount St. Helens volcano. J. Volcanol. Geotherm. Res., 66, 185-202. doi: 10.1016/0377-0273(94)00059-P

Caseldine, C., Hatton, J., Huber, U., Chiverrell, R., Woolley, N., 1998. Assessing the impact of volcanic activity on mid-Holocene climate in Ireland: the need for replicate data. Holocene 8, 105-111. doi: 10.1191/095968398676397681

Chambers, F.M., Daniel, J.R.G., Hunt, J.B., Molloy, K., O'Connell, M., 2004.

Tephrostratigraphy of An Loch Mór, Inir Oírr, western Ireland: implications for Holocene tephrochronology in the northeastern Atlantic region. Holocene 14, 703-720. doi: 10.1191/0959683604hl749rp

Chertkoff, D.G., Gardner, J.E., 2004. Nature and timing of magma interactions before, during, and after the caldera-forming eruption of Volcán Ceboruco, Mexico. Contrib. Mineral. Petrol. 146, 715-735. doi: 10.1007/s00410-003-0530-6 Coulter, S.E., Pilcher, J.R., Plunkett, G., Baillie, M.G.L., Hall, V.A., Steffensen, J.P., Vinther, B.M., Clausen, H.B., Johnsen, S.J., 2012. Holocene tephras highlight complexity of volcanic 
signals in Greenland ice cores. J. Geophys. Res. - Atmos. 117, D21303, doi:

10.1029/2012JD017698

D’Andrea, W.J., Vaillencourt, D.A., Balascio, N.L., Werner, A., Roof, S.R., Retelle, M., Bradley, R.S., 2012. Mild Little Ice Age and unprecedented recent warmth in an 1800 year lake sediment record from Svalbard. Geol. 40, 1007-1010. doi: 10.1130/G33365.1

Davies, S.M., Elmquist, M., Bergman, J., Wohlfarth, B., Hammarlund, D., 2007. Cryptotephra sedimentation processes within two lacustrine sequences from west central Sweden. Holocene 17, 319-330. doi: 10.1177/0959683607076443

Davies, S.M., Larsen, G., Wastegård, S., Turney, C.S., Hall, V.A., Coyle, L., Thordarson, T., 2010. Widespread dispersal of Icelandic tephra: how does the Eyjafjöll eruption of 2010 compare to past Icelandic events? J. Quat. Sci. 25, 605-611. doi: 10.1002/jqs.1421 Davies, L.J., Jensen, B.J., Froese, D.G., Wallace, K.L., 2016. Late Pleistocene and Holocene tephrostratigraphy of interior Alaska and Yukon: Key beds and chronologies over the past 30,000 years. Quat. Sci. Rev. 146, 28-53. doi: 10.1016/j.quascirev.2016.05.026 Dugmore, A.J., Newton, A.J., Sugden, D.E., Larsen, G., 1992. Geochemical stability of finegrained silicic Holocene tephra in Iceland and Scotland. J. Quat. Sci. 7, 173-183. doi: $10.1002 /$ jqs.3390070208

Dugmore, A.J., Cook, G.T., Shore, J.S., Newton, A.J., Edwards, K.J., Larsen, G., 1995. Radiocarbon dating tephra layers in Britain and Iceland. Radiocarbon 37, 379-388. doi: https://doi.org/10.1017/S003382220003085X

Dugmore, A.J., Church, M.J., Mairs, K.A., McGovern, T.H., Perdikaris, S. and Vesteinsson, O. 2007 Abandoned farms, volcanic impacts, and woodland management: Revisiting Pjórsárdalur, the 'Pompeii of Iceland'. Arct. Anthropol. 44, 1-11. doi: 10.1353/arc.2011.0021 Dugmore, A.J., Newton, A.J., Smith, K.T., Mairs, K.A., 2013. Tephrochronology and the late Holocene volcanic and flood history of Eyjafjallajökull, Iceland. J. Quat. Sci. 28, 237-247. doi: $10.1002 /$ jqs. 2608

Egan, J., 2016. Impact and significance of tephra deposition from Mount Mazama and Holocene climate variability in the Pacific Northwest USA. Unpubl. PhD thesis, University of Manchester.

Egan, J., Staff, R., Blackford, J., 2015. A high-precision age estimate of the Holocene Plinian eruption of Mount Mazama, Oregon, USA. Holocene 25, 1054-1067. doi:

$10.1177 / 0959683615576230$ 
Fyfe, R., Anderson, P., Barnett, R., Blake, W., Daley, T., Head, K., MacLeod, A., Matthews, I., Smith, D., 2014. Vegetation and climate change on Exmoor over the last millennium: detailed analysis of Ricksby Ball. Unpublished report to South West Water (http://www.southwestwater.co.uk/media/pdf/5/5/Vegetation_and_climate_change_on_E xmoor_Fyfe_et_al_2014.pdf; accessed 5 Dec., 2015).

Fyfe, R.M., Blackford, J.J., Hardiman, M., Hazell, Z., MacLeod, A., Perez, M., Littlewood, S., 2016. The environment of the Whitehorse Hill cist. In A.M. Jones (Ed.), Preserved in the Peat: an extraordinary Bronze Age burial on Whitehorse Hill, Dartmoor, and its wider context, Oxbow, Oxford, 158-181.

Gardner, J.E., Tait, S., 2000. The caldera-forming eruption of Volcán Ceboruco, Mexico. Bull. Volcanol. 62, 20-33. doi: 10.1007/s004450050288

Grönvold, K., Óskarsson, N., Johnsen, S.J., Clausen, H.B., Hammer, C.U., Bond, G., Bard, E., 1995. Ash layers from Iceland in the Greenland GRIP ice core correlated with oceanic and land sediments. Earth Planet. Sci. Lett. 135, 145-155. doi: 10.1016/0012-821X(95)00145-3 Gudmundsdóttir, E.R, Larsen, G., Eiríksson, J., 2011. Two new Icelandic tephra markers: The Hekla Ö tephra layer, 6060 cal. yr BP, and Hekla DH tephra layer, 6650 cal. yr BP. Land-sea correlation of mid-Holocene tephra markers. Holocene 21, 629-639. doi:

$10.1177 / 0959683610391313$

Gudmundsdóttir, E.R., Larsen, G., Eiríksson, J., 2012. Tephra stratigraphy on the North Icelandic shelf: extending tephrochronology into marine sediments off North Iceland. Boreas 41, 719-734. doi: 10.1111/j.1502-3885.2012.00258.x

Gudmundsdóttir, E.R., Larsen, G., Björck, S., Ingólfsson, Ó., Striberger, J., 2016. A new highresolution Holocene tephra stratigraphy in eastern Iceland: Improving the Icelandic and North Atlantic tephrochronology. Quat. Sci. Rev. 150, 234-249. doi:

10.1016/j.quascirev.2016.08.011

Hall, V.A., Pilcher, J.R., 2002. Late-Quaternary Icelandic tephras in Ireland and Great Britain: detection, characterization and usefulness. Holocene 12, 223-230. doi:

$10.1191 / 0959683602 \mathrm{hl} 538 \mathrm{rr}$

Hannon, G.E., Hermanns-Audardottir, M., Wastegård, S., 1998. Human impact at Tjørnuvík in the Faroe Islands. Frodskaparrit 46, 215-228.

Hartley, M.E., Thordarson, T., de Joux, A., 2016. Postglacial eruptive history of the Askja region, North Iceland. Bull. Volcanol. 78, 28. doi: 10.1007/s00445-016-1022-7 
Holmes, N., Langdon, P.G., Caseldine, C.J., Wastegård, S., Leng, M.J., Croudace, I.W., Davies, S.M., 2016. Climatic variability during the last millennium in Western Iceland from lake sediment records. Holocene 26, 756-771. doi: 10.1177/0959683615618260 Jensen, B., Pyne-O'Donnell, S., Plunkett, G., Froese, D.G., Hughes, P.D. M., Sigl, M., McConnell, J.R., Amesbury, M.J., Blackwell, P.G., van den Bogaard, C., Buck, C.E., Charman, D.J., Clague, J.J., Hall, V., Koch, J., Mackay, H., Mallon, G., McColl, L., Pilcher, J.R., 2014. Transatlantic distribution of the Alaskan White River Ash. Geol. 42, 875-878. doi: $10.1130 / G 35945.1$

Johansson, H., Lind, E.M., Wastegård, S., 2017. Compositions of glass in proximal tephras from eruptions in the Azores archipelago and their links with distal sites in Ireland. Quat. Geochron. 40, 120-128. doi: 10.1016/j.quageo.2016.07.006

Kaufman, D.S., Jensen, B.J.L., Reyes, A.V., Schiff, C.J., Froese, D.G., Pearce, N.J.G., 2012. Late Quaternary tephrostratigraphy, Ahklun Mountains, SW Alaska. J. Quat. Sci. 27, 344-359. doi: $10.1002 /$ jqs.1552

Koren, J.H., Svendsen, J.I., Mangerud, J. and Furnes, H., 2008. The Dimna Ash - a 12.8 C-14 ka-old volcanic ash in Western Norway. Quat. Sci. Rev. 27, 85-94. doi: 10.1016/j.quascirev.2007.04.021

Kuehn, S.C., Froese, D.G., Shane, P.A.R., INTAV Intercomparison Participants, 2011. The INTAV intercomparison of electron-beam microanalysis of glass by tephrochronology laboratories: results and recommendations. Quat. Int. 246, 19-47. doi: 10.1016/j.quaint.2011.08.022

Kyle, P.R., Ponomareva, V.V., Rourke Schluep, R., 2011. Geochemical characterization of marker tephra layers from major Holocene eruptions in Kamchatka, Russia. Int. Geol. Rev. 53, 1059-1097. doi: 10.1080/00206810903442162 Langdon, P.G., Barber, K.E., 2002. The 'AD 860' tephra in Scotland: new data from Langlands Moss, East Kilbride, Strathclyde. Quat. Newsl. 97, 11-18.

Larsen, G., 1984. Recent volcanic history of the Veidivötn fissure swarm, southern Iceland an approach to volcanic risk assessment. J. Volcanol. Geotherm. Res. 22, 33-58. doi: $10.1016 / 0377-0273(84) 90034-9$ Larsen, G., Eiríksson, J., 2008. Late Quaternary terrestrial tephrochronology of Iceland frequency of explosive eruptions, type and volume of tephra deposits. J. Quat. Sci. 23, 109120. doi: 10.1002/jqs.1129 
Larsen, G., Thórarinsson, S., 1977. H4 and other acid tephra layers. Jökull 27, 28-46. Larsen, G., Dugmore, A.J., Newton, A.J., 1999. Geochemistry of historic silicic tephras in Iceland. Holocene 9, 463-471. doi: 10.1191/095968399669624108 Larsen, G., Newton, A.J., Dugmore, A.J., Vilmundardóttir, E.G., 2001. Geochemistry, dispersal, volumes and chronology of Holocene silicic tephra layers from the Katla volcanic system, Iceland. J. Quat. Sci. 16, 119-132. doi: 10.1002/jqs.587 Larsen, G., Eiríksson, J., Knudsen, K.L., Heinemeier, J., 2002. Correlation of late Holocene terrestrial and marine tephra markers, North Iceland: implications for reservoir age changes. Polar Res. 21, 283-290. doi: 10.3402/polar.v21i2.6489 Larsen, G., Eiríksson, J., Gudmundsdóttir, E.R., 2014. Last millennium dispersal of air-fall tephra and ocean-rafted pumice towards the north Icelandic shelf and the Nordic seas. Geol. Soc., Lond., Special Publ. 398, 113-140. doi: 10.1144/SP398.4 Lawson, I.T., Swindles, G.T., Plunkett, G., Greenberg, D., 2012. The spatial distribution of Holocene cryptotephras in north-west Europe since $7 \mathrm{ka}$ : implications for understanding ash fall events from Icelandic eruptions. Quat. Sci. Rev. 41, 57-66. doi:

10.1016/j.quascirev.2012.02.0

Le Bas, M.J., Le Maitre, R.W., Streckeisen, A., Zanettin, B., 1986. A chemical classification of volcanic rocks based on the total alkali silica diagram. J. Petrol. $27,745-750$. doi: 10.1093/petrology/27.3.745

Lind, E.M., Lilja, C., Wastegård, S., Pearce, N.J., 2016. Revisiting the Borrobol Tephra. Boreas 45, 629-643. doi: 10.1111/bor.12176

Liu, E.J., Cashman, K.V., Beckett, F.M., Witham, C.S., Leadbetter, S.J., Hort, M.C., Guðmundsson, S., 2014. Ash mists and brown snow: Remobilization of volcanic ash from recent Icelandic eruptions. J. Geophys. Res. - Atmos. 119, 9463-9480. doi: 10.1002/2014JD021598 Mackay, H., Hughes, P.D.M., Jensen, B.J.L., Langdon, P.G., Pyne-O'Donnell, S.D.F., Plunkett, G., Froese, D.G., Coulter, S., Gardner, J., 2016. A mid to late Holocene cryptotephra framework from eastern North America. Quat. Sci. Rev.132, 101-113. doi: 10.1016/j.quascirev.2015.11.011 Mangerud, J., Lie, S.E., Furnes, H., Kristiansen, I.L., Lømo, L., 1984. A Younger Dryas ash bed in western Norway, and its possible correlations with tephra in cores from the Norwegian Sea and the North Atlantic. Quat. Res. 21, 85-104. doi: 10.1016/0033-5894(84)90092-9 
Matthews. I., 2008. Roman Lode, Exmoor, Devon: Tephrochronology Scientific Dating Report. Research Department Rep. Ser. no. 26-2008, English Heritage, Portsmouth. Monteath, A.J., van Hardenbroek, M., Davies, L.J., Froese, D.G., Langdon, P.G., Xu, X., Edwards, M.E., 2017. Chronology and glass chemistry of tephra and cryptotephra horizons from lake sediments in northern Alaska, USA. Quat. Res. 88, 169-178. doi: 10.1017/qua.2017.38

Navrátil, T., Hladil, J., Strnad, L., Koptíková, L., Skála, R., 2013. Volcanic ash particulate matter from the 2010 Eyjafjallajökull eruption in dust deposition at Prague, central Europe. Aeolian Res. 9, 191-202. doi: 10.1016/j.aeolia.2012.12.002

Nooren, C.A.M., Hoek, W.Z., Tebbens, L.A., Martin Del Pozzo, A.L., 2009.

Tephrochronological evidence for the late Holocene eruption history of El Chichón Volcano, Mexico. Geofísica Int. 48, 97-112.

Óladóttir, B.A., Larsen, G., Thordarson, T. and Sigmarsson, O., 2005. The Katla volcano SIceland: Holocene tephra stratigraphy and eruption frequency. Jökull 55, 53-74.

Óladóttir, B.A., Sigmarsson, O., Larsen, G., Thordardson, T., 2008. Katla volcano, Iceland: magma composition, dynamic and eruption frequency as recorded by Holocene tephra layers. Bull. Volcanol. 70, 475-493. doi: 10.1007/s00445-007-0150-5 Óladóttir, B.A., Larsen, G., Sigmarsson, O., 2011. Holocene volcanic activity at Grímsvötn, Bárdarbunga and Kverkfjöll subglacial centres beneath Vatnajökull, Iceland. Bull. Volcanol. 73, 1187-1208. doi: 10.1007/s00445-011-0461-4 Palais, J.M., Taylor, K., Mayewski, P.A., Grootes, P., 1991. Volcanic ash from the 1362 A.D. Oræfajokull eruption (Iceland) in the Greenland ice sheet. Geophys. Res. Lett. 18, 12411244. doi: 10.1029/91GL01557

Payne, R., Blackford, J., van der Plicht, J., 2008. Using cryptotephras to extend regional tephrochronologies: an example for southeast Alaska and implications for hazard assessment. Quat. Res. 69, 42-55. doi: 10.1016/j.yqres.2007.10.007

Persson, C., 1971. Tephrochronological investigations of peat deposits in Scandinavia and on the Faroe Islands. Sver. Geol. Undersokning Arb. 65, 1-34.

Pilcher, J.R., Hall, V.A., 1992. Towards a tephrochronology for the Holocene of the north of Ireland. Holocene 2, 255-259. doi: 10.1177/095968369200200307

Pilcher, J.R., Hall, V.A., McCormac, F.G., 1995. Dates of Holocene Icelandic volcanic eruptions from tephra layers in Irish peats. Holocene 5, 103-110. doi: 10.1177/095968369500500111 
Pilcher, J.R., Baillie, M.G.L., Brown, D.M., McCormac, F.G., 1996. Hydrological data from the long Irish subfossil oak records. In J.S. Dean, D.M. Meko, T.W. Swetman (eds), Tree Rings, Environment and Humanity, Proceedings of the International Conference, Tucson, Arizona, 17-21 May 1994, Radiocarbon 1996, 259-264.

Pilcher, J.R., Bradley, R.S., Francus, P., Anderson, L., 2005. A Holocene tephra record from the Lofoten Islands, Arctic Norway. Boreas 34, 136-156. doi: 10.1111/j.15023885.2005.tb01011.x

Plunkett, G.M. 1999. Environmental change in the Late Bronze Age in Ireland (1200-600 cal. BC). Unpubl. PhD thesis, Queen's University Belfast, Belfast.

Plunkett, G., 2006. Hekla 3, environmental downturn and Irish Late Bronze Age hillfort connections revisited. Emania 20, 55-60.

Plunkett, G.M., Pilcher, J.R., McCormac, F.G., Hall, V.A., 2004a. New dates for first millennium BC tephra isochrones in Ireland. Holocene 14, 780-786. doi:

$10.1191 / 0959683604 \mathrm{hl} 757 \mathrm{rr}$

Plunkett, G.M., Whitehouse, N.J., Hall, V.A., Brown, D.M., Baillie, M.G.L., 2004b. A preciselydated lake-level rise marked by diatomite formation in northeastern Ireland. J. Quat. Sci. 19, 3-7. doi: 10.1002/jqs.816

Plunkett, G., Coulter, S.E., Ponomareva, V.V., Blaauw, M., Klimaschewski, A., Hammarlund, D., 2015. Distal tephrochronology in volcanic regions: Challenges and insights from Kamchatkan lake sediments. Glob. Planet. Change 134, 26-40. doi:

10.1016/j.gloplacha.2015.04.006

Ponomareva, V.V., Portnyagin, M., Pevzner, M., Blaauw, M., Kyle, P., Derkachev, A., 2015. Tephra from andesitic Shiveluch volcano, Kamchatka, NW Pacific: chronology of explosive eruptions and geochemical fingerprinting of volcanic glass. Int. J. Earth Sci. 104, 1459-1482, doi: 10.1007/s00531-015-1156-4

Ponomareva, V., Portnyagin, M., Pendea, I.F., Zelenin, E., Bourgeois, J., Pinegina, T., Kozhurin, A., 2017. A full Holocene tephrochronology for the Kamchatsky Peninsula region: Applications from Kamchatka to North America. Quat. Sci. Rev. 168, 101-122. doi: 10.1016/j.quascirev.2017.04.031

Preece, S.J., McGimsey, R.G., Westgate, J.A., Pearce, N.J.G., Hart, W.K., Perkins, W.T., 2014. Chemical complexity and source of the White River Ash, Alaska and Yukon. Geosphere GES00953-1. doi: 10.1130/GES00953.1 
Pyne-O'Donnell, S.D.F, Hughes, P.D.M., Froese, D.G., Jensen, B.J.L., Kuehn, S.C., Mallon, G., Amesbury, M.J., Charman, D.J., Daley, T.J., Loader, N.J., Mauquoy, D., Street-Perrott, F.A., Woodman-Ralph, J., 2012. High-precision ultra-distal Holocene tephrochronology in North America. Quat. Sci. Rev. 52, 6-11. doi: 10.1016/j.quascirev.2012.07.024 Reilly, E., Mitchell, F.J.G., 2015. Establishing chronologies for woodland small hollow and more humus deposits using tephrochronology and radiocarbon dating. Holocene 25, 241252. doi: $10.1177 / 0959683614557571$

Samolczyk, M.A., Vallance, J.W., Cubley, J.F., Osborn, G.D., Clark, D.H., 2016. Geochemical characterization and dating of $\mathrm{R}$ tephra, a postglacial marker bed in Mount Rainier National Park, Washington, USA. Canadian J. Earth Sciences 53, 202-217. doi: 10.1139/cjes-20150115

Siebert, L., Begét, J.E., Glicken, H., 1995. The 1883 and late-prehistoric eruptions of Augustine volcano, Alaska. J. Volcanol. Geotherm. Res. 66, 367-395. doi: 10.1016/03770273(94)00069-S

Siebert, L., Simkin, T., Kimberly, P. 2010 Volcanoes of the World (third edition), University of California Press, Berkeley.

Sieron, K., Siebe, C., 2008. Revised stratigraphy and eruption rates of Ceboruco stratovolcano and surrounding monogenetic vents (Nayarit, Mexico) from historical documents and new radiocarbon dates. J. Volcanol. Geotherm. Res. 176, 241-264. doi: 10.1016/j.jvolgeores.2008.04.006

Sisson, T.W., Vallance, J.W., 2009. Frequent eruptions of Mount Rainier over the last $\sim 2,600$ years. Bull. Volcanol. 71, 595-618. doi: 10.1007/s00445-008-0245-7

Stevenson, J.A., Loughlin, S., Rae, C., Thordarson, T., Milodowski, A.E., Gilbert, J.S., Harangi, S., Lukács, R., Højgaard, B., Árting, U., Pyne-O'Donnell, S., 2012. Distal deposition of tephra from the Eyjafjallajökull 2010 summit eruption. J. Geophys. Res. - Solid Earth 117, B00C10. doi: 10.1029/2011JB008904

Stevenson, J.A., Loughlin, S.C., Font, A., Fuller, G.W., MacLeod, A., Oliver, I.W., Jackson, B., Horwell, C.J., Thordarson, T., Dawson, I., 2013. UK monitoring and deposition of tephra from the May 2011 eruption of Grímsvötn, Iceland. J. Appl. Volcanol. 2: 3. doi: 10.1186/2191$5040-2-3$ 
Streeter, R., Dugmore, A., 2014. Late-Holocene land surface change in a coupled social ecological system, southern Iceland: a cross-scale tephrochronology approach. Quat. Sci. Rev. 86, 99-114. doi: 10.1016/j.quascirev.2013.12.016 Sun, C., Plunkett, G., Liu, J., Zhao, H., Sigl, M., McConnell, J.R., Pilcher, J.R., Vinther, B., Steffensen, J.P., Hall, V., 2014. Ash from Changbaishan Millennium eruption recorded in Greenland ice: implications for determining the eruption's timing and impact. Geophys. Res. Lett. 41, 694-701. doi: 10.1002/2013GL058642

Swindles, G.T., Lawson, I.T., Savov, I.P., Connor, C.B., Plunkett, G., 2011. A 7000-year perspective on volcanic ash clouds affecting Northern Europe. Geol. 39, 887-890. doi: $10.1130 / G 32146.1$

Tappen, C.M., Webster, J.D., Mandeville, C.W., Roderick, D., 2009. Petrology and geochemistry of ca. 2100-1000 aBP magmas of Augustine volcano, Alaska, based on analysis of prehistoric pumiceous tephra. J. Volcanol. Geotherm. Res. 183, 42-62. doi: 10.1016/j.jvolgeores.2009.03.007 Thorarinsson, S., 1954. The Tephra-Fall from Hekla on March 29th 1947. In T. Einarsson, G. Kjartnsson, S. Thorarinsson, The Eruption of Hekla 1947-48, Societas Scientarum Islandica, Reyjavík, II-3, 1-68.

Thorarinsson, S., 1981. Greetings from Iceland. Ash-falls and volcanic aerosols in Scandinavia. Geograf. Annaler, Series A. Phys. Geogr. 63, 109-118. doi: $10.1080 / 04353676.1981 .11880024$ Turney, C.S.M., Harkness, D.D., Lowe, J.J., 1997. The use of microtephra horizons to correlate Late-glacial lake sediment successions in Scotland. J. Quat. Sci. 12, 525-531. doi: 10.1002/(SICI)1099-1417(199711/12)12:6<525::AID-JQS347>3.0.CO;2-M Vallance, J.W., Scott, K.M., 1997. The Osceola Mudflow from Mount Rainier: Sedimentology and hazard implications of a huge clay-rich debris flow. Geol. Soc. Amer. Bull. 109, 143-163. doi: 10.1130/0016-7606(1997)109<0143:TOMFMR>2.3.CO;2 van den Bogaard, C., Schmincke, H.-U., 2002. Linking the North Atlantic to central Europe: a high-resolution Holocene tephrochronological record from northern Germany. J. Quat. Sci. 17, 3-20. doi: 10.1002/jqs.636 van der Bilt, W.G., Lane, C.S., Bakke, J., 2017. Ultra-distal Kamchatkan ash on Arctic Svalbard: Towards hemispheric cryptotephra correlation. Quat. Sci. Rev. 164, 230-235. doi: 10.1016/j.quascirev.2017.04.007 
Vorren, K.-D., Blaauw, M., Wastegård, S., van der Plicht, J., Jensen, C., 2007. High-resolution stratigraphy of the northernmost concentric raised bog in Europe: Sellevollmyra, And $\varnothing y a$, northern Norway. Boreas 36, 253-277. doi: 10.1111/j.1502-3885.2007.tb01249.x Wallace, K.L., Coombs, M.L., Hayden, L.A., Waythomas, C.F., 2014. Significance of a nearsource tephra-stratigraphic sequence to the eruptive history of Hayes Volcano, southcentral Alaska: U.S. Geological Survey Scientific Investigations Report 2014-5133, http://pubs.usgs.gov/sir/2014/5133/ (accessed 27/08/2017).

Wastegård, S., 2002. Early to middle Holocene silicic tephra horizons from the Katla volcanic system, Iceland: new results from the Faroe Islands. J. Quat. Sci. 17, 723-730. doi: $10.1002 / j q s .724$

Wastegård, S., 2005. Late Quaternary tephrochronology of Sweden: a review. Quat. Int. 130, 49-62. doi: 10.1016/j.quaint.2004.04.030

Wastegård, S., Davies, S.M., 2009. An overview of distal tephrochronology in northern Europe during the last 1000 years. J. Quat. Sci. 24, 500-512. doi: 10.1002/jqs.1269 Wastegård, S., Björck, S., Possnert, G. and Wohlfarth, B., 1998. Evidence of the occurrence of Vedde Ash in Sweden: radiocarbon age estimates. J. Quat. Sci. 13, 271-274. doi: 10.1002/(SICI)1099-1417(199805/06)13:3<271::AID-JQS372>3.0.CO;2-4 Wastegård, S., Wohlfarth, B., Subetto, D.A., Salpeko, T.V., 2000. Extending the known distribution of the Younger Dryas Vedde Ash into northwestern Russia. J. Quat. Sci. 15, 581586. doi: 10.1002/1099-1417(200009)15:6<581::AID-JQS558>3.0.CO;2-3

Wastegård, S., Björck, S., Grauert, M., Hannon, G.E., 2001. The Mjáuvøtn tephra and other Holocene tephra horizons from the Faroe Islands: a link between the Icelandic source region, the Nordic Seas, and the European continent. Holocene 11, 101-109. doi: $10.1191 / 095968301668079904$

Wastegård, S., Hall, V.A., Hannon, G.E., van den Bogaard, C., Pilcher, J.R., Sigurgeirsson, M.Á., Hermanns-Audardóttir, M., 2003. Rhyolitic tephra horizons in northwestern Europe and Iceland from the AD 700s-800s: a potential alternative for dating first human impact. Holocene 13, 277-283. doi: 10.1191/0959683603hl617rr Wastegård, S., Andersson, S., Perkins, V.H., 2009. A new mid-Holocene tephra in central Sweden. GFF 131, 293-297. doi: 10.1080/11035890903452662 
Watson, E.J., Swindles, G.T., Lawson, I.T., Savov, I.P., 2016. Do peatlands or lakes provide the most comprehensive distal tephra records? Quat. Sci. Rev. 139, 110-128. doi:

10.1016/j.quascirev.2016.03.011

Watson, E.J., Swindles, G.T., Lawson, I.T., Savov, I.P., Wastegård, S., 2017a. The presence of Holocene cryptotephra in Wales and southern England. J. Quat. Sci. 32, 493-500. doi: $10.1002 /$ jqs.2942

Watson, E.J., Swindles, G.T., Savov, I.P., Lawson, I.T., Connor, C.B., Wilson, J.A., 2017b. Estimating the frequency of volcanic ash clouds over northern Europe. Earth Planet. Sci. Lett. 460, 41-49. doi: 10.1016/j.epsl.2016.11.054

Westgate, J.A., 1977. Identification and significance of late Holocene tephra from Otter Creek, southern British Columbia, and localities in west-central Alberta. Canadian J. Earth Sciences 14, 2593-2600. doi: 10.1139/e77-224

Wulf, S., Dräger, N., Ott, F., Serb, J., Appelt, O., Gudmundsdóttir, E., van den Bogaard, C., Słowiński, M., Błaszkiewicz, M., Brauer, A., 2016. Holocene tephrostratigraphy of varved sediment records from Lakes Tiefer See (NE Germany) and Czechowskie (N Poland). Quat. Sci. Rev. 132, 1-14. doi: 10.1016/j.quascirev.2015.11.007

Yamaguchi, D.K., 1983. New tree-ring dates for recent eruptions of Mount St. Helens. Quat. Res. 20, 246-250. doi: 10.1016/0033-5894(83)90080-7

Yamaguchi, D.K., 1985. Tree-ring evidence for a two-year interval between recent prehistoric explosive eruptions of Mount St. Helens. Geol. 13, 554-557. doi: 10.1130/00917613(1985)13<554:TEFATI>2.0.CO;2

Zdanowicz, C.M., Zielinski, G.A., Germani, M.S., 1999. Mount Mazama eruption: Calendrical age verified and atmospheric impact assessed. Geol. 27, 621-624. doi: 10.1130/00917613(1999)027<0621:MMECAV>2.3.CO;2

Zielinski, G.A., Germani, M.S., Larsen, G., Baillie, M.G.L., Whitlow, S., Twickler, M.S., Taylor, K., 1995. Evidence of the Eldgjá (Iceland) eruption in the GISP2 Greenland ice core: relationship to eruption processes and climate conditions in the tenth century. Holocene 5, 129-140. doi: 10.1177/095968369500500201

Zielinski, G.A., Mayewski, P.A., Meeker, L.D., Whitlow, S., Twickler, M.A., 1996. A 111,000-yr record of explosive volcanism from the GISP2 (Greenland) ice core. Quat. Res. 45, 109-118. doi: $10.1006 /$ qres.1996.0013 
Zillén, L.M., Wastegård, S., Snowball, I.F., 2002. Calendar year ages of three mid-Holocene tephra layers identified in varved lake sediments in west central Sweden. Quat. Sci. Rev. 21, 1583-1591. doi: 10.1016/S0277-3791(02)00036-7 